\title{
ENCUENTROS CON LA MÚSICA EN EL ESTUDIO DE LA HISTORIA DEL ARTE: LA APORTACIÓN DEL MONASTERIO DE SAN MILLÁN DE LA COGOLLA (LA RIOJA)
}

\author{
M. - Begoña Arrúe Ugarte \\ Universidad de La Rioja
}

\begin{abstract}
RESUMEN: Este artículo tiene por objetivo informar sobre el encuentro del historiador del arte con la musicología en la práctica de su profesión y ofrecerle objetos de conocimiento para un análisis especializado, a partir la investigación de un monumento, el monasterio de San Millán de la Cogolla, declarado por la UNESCO en 1997 Patrimonio de la Humanidad. Se analiza la presencia de la música en las artes plásticas a través de la iconografía de la vida de san Millán, con representaciones desde el siglo XI de la cítara utilizada en su vida pastoril, y otros cordófonos e instrumentos de viento descubiertos y/o restaurados en las últimas intervenciones conservadoras de la iglesia del edificio de Yuso. Así mismo, se ofrecen las aportaciones de las fuentes documentales sobre la importancia del coro en la vida monástica, las actividades con él relacionadas y la adquisición de instrumentos musicales. Por último, se dan a conocer grafitos inéditos en el antiguo noviciado benedictino en los que se representan escrituras musicales con inscripciones relativas a cantos o danzas, de los siglos XVII y XVIII.
\end{abstract}

Palabras clave: Historia del arte, música, patrimonio, monasterio, San Millán de la Cogolla, instrumentos musicales, cítara, cordófono, coro, libro de coro, órgano, grafito, escritura musical.

\section{ENCOUNTERS WITH MUSIC IN THE STUDY OF THE HISTORY OF ART: THE CONTRIBUTION OF THE MONASTERY OF SAN MILLÁN DE LA COGOLLA (LA RIOJA)}

ABSTRACT: This article aims to report on the encounter between art history and musicology within the professional practice of the art historian and, in this 
context, to provide the musicologist new knowledge elements for further specialized research. The study has been conducted in the Monastery of San Millán de la Cogolla (La Rioja, Spain), a monument declared World Heritage Site by UNESCO in 1997. First, we analyze the presence of music in the plastic arts through the iconography of saint Aemilian biography, including representations, from the XI century and onwards, of the zither instrument used in shepherd life and other cordophone and wind instruments either discovered or restored during the last conservation works at the church of the Yuso Monastery. Several references taken from different documentary sources on the significance of the choir in the monastic life, the varied activities related to the choir area and the acquisition of musical instruments are also given. Finally, the paper presents unknown graffiti we have recently found in the ancient benedictine novitiate, in which musical symbols and notations on songs and dances from the XVII and XVIII centuries are represented.

Keywords: Art history, music, heritage, monastery, San Millan de la Cogolla, musical instruments, zither, cordophone, choir, choir book, organ, graffiti, musical notation.

El encuentro con la música por parte del historiador del arte en el desarrollo de su profesión suele producirse en dos niveles de conocimiento de diferente índole. Uno, teórico, en el que el arte de la música se vincula a las artes visuales desde variadas perspectivas que tratan de concretar el encadenamiento de relaciones existentes entre las distintas formas de creación artística. Sea el punto de partida de las reflexiones el pensamiento de Platón, Vitruvio, San Agustín, Alberti, Leonardo, Lessing, o Le Corbusier, desde las fuentes de la Antigüedad y la edad Media, los teóricos del Renacimiento o del Barroco, a las interpretaciones del mundo contemporáneo, la profundización en esta materia ha dado lugar a una extensa historiografía por la que podemos conocer cómo se asemejan, utilizan y combinan los conceptos de composición, ritmo, armonía, tono, intervalo, movimiento, etc. en la arquitectura y en las artes plásticas'. El análisis se efectúa a partir de diversas disciplinas y metodologías (filosofía, estética, matemática, historia, historia del arte, musicología, pedagogía, antropología, filología, etc.). En relación con el objeto de la historia del arte, los estudios se han centrado preferentemente en la comparación de la música con la arquitectura, en búsqueda de sus relaciones

1. A modo de ejemplo, ver Gomis Corell, J. C., "Arquitectura i música en Vitruvi. L'harmonía musical al De Architectura Libri Decem", Ars Longa, 16 (2007), pp. 13-21, o Villanueva, C. (ed. y coord.), El pórtico de la Gloria. Música, arte y pensamiento. Santiago de Compostela, 1988 (2 $2^{\mathrm{a}}$ ed. 2011). 
numéricas, y con la pintura, tratando de hallar paralelismos entre el sonido y el color, o la línea ${ }^{2}$. No obstante, una buena parte de las aportaciones procede del análisis formalista, por el que se han dado a conocer la representación en pintura y escultura de músicos ${ }^{3}$, instrumentos musicales, o escenas relacionadas con su interpretación y audición, o bien de carácter iconográfico e iconológico, abundando en el simbolismo de ciertos programas artísticos utilizados en el exorno arquitectónico o en el estudio de la icnografía y el sentido alegórico de la composición geométrica y aritmética de la arquitectura ${ }^{4}$. Tanto la evidencia de relaciones entre las artes, como la distinción entre ellas y el "paragone", que tanto ejercitó la literatura artística renacentista, se han manifestado desde antiguo, y los juegos de palabras han sido repetidamente utilizados y analizados (la arquitectura como música congelada, de Simónides, la pintura como poesía muda, de Plutarco, o el "ut pictura poesis", de Horacio). Es fácil que las creaciones de las artes se encuentren e intercambien, y sus formas sean comparables, pero, como señaló Susanne Langer, "cada obra tiene su aparición primaria, con respecto de la cual son secundarias todas las demás dimensiones virtuales. No hay casamientos felices en el arte... sólo violaciones afortunadas" ${ }^{\prime \prime}$. El historiador del arte se encontrará con la música en su estudio de la teoría del arte o la historia de la crítica del arte, y en la investigación de las artes visuales analizará las relaciones de éstas con la música, aplicando metodologías, como las arriba citadas, sin perder de vista el modo de aparición de las obras, es decir, su dimensión histórica y artística, y el lenguaje formal con el que se presentan. Por consiguiente, no se alejará del objeto de su disciplina, al margen de su interés por la filosofía y la

2. La aleatoriedad de muchos de estos sondeos fue puesta de relieve por Gillo Dorfles en II Divenire delle arti (Turín, 1959; $1^{a}$ ed. española, El devenir de las artes, México, 1963; $3^{\underline{a}}$ reimp. México, Fondo de Cultura Económica, 1993, ver Segunda parte, cap. II. La Música (pp. 137163), donde, admitiendo la capacidad transmisora de conceptos en su lenguaje, considera "indudable que, en la mayoría de los casos, la música no es otra cosa que pura expresividad de imágenes sonoras sin voluntad alguna significativa, y en esto absolutamente afín a la pintura Ilamada hoy 'no representativa', o a cierta arquitectura que no es únicamente utilitaria" (p. 137).

3. Un ejemplo es la exposición Protagonistas del arte. Retratos en la Academia, organizada en 2011 por la Real Academia de Bellas Artes de San Fernando, en la que se integraban retratos de Farinelli y otros músicos, a los que dedicó una conferencia el académico D. Antonio Gallego (texto en Crónica 2011. Real Academia de Bellas Artes de San Fernando, Madrid, 2012, pp. 136-147).

4. Véanse los estudios de Juan Francisco Esteban Lorente y su Tratado de Iconografía (Madrid, Istmo, 1990) en el que dedica un apartado a este tema, así como otros a las armonías musicales, los sistemas proporcionales y los números, con bibliografía (op. cit., cap. I. 3 a 6, pp. 38-82).

5. Langer, S., Los problemas del arte, Buenos Aires, 1966, p. 90. En la conferencia recogida en este libro con el título "Analogías engañosas. Relaciones especiosas y reales entre las artes", la filósofa concluye con una referencia al fenómeno de la "abstracción última" o "trascendencia": "Aquí es donde todas las artes "aspiran a la condición de música" y la música se torna una visión intemporal del sentimiento" (p. 93). Esta visión simbólica no dejaría de ser también parcial para Dorfles (El devenir..., p. 137). 
estética, ofreciendo a la de música información concerniente a ella, preferentemente descriptiva, de imágenes históricas o realizaciones arquitectónicas y plásticas. Es éste el segundo nivel de conocimiento aludido al comienzo, el de la aplicación práctica de su especialización. Cómo se produce el encuentro dependerá de sus líneas de investigación y de qué modo se definirá, de la disposición y curiosidad del historiador por la materia.

El preámbulo anterior viene a justificar el contenido de este artículo. El cruce de ciencias que voy a exponer se inserta en el segundo nivel, pero no se trata propiamente de una reflexión sobre música e imagen, sino de un acercamiento al valor y efecto de la música a partir del análisis de su presencia en las fuentes histórico-artísticas que han servido a la investigación de un monumento: el monasterio de San Millán de la Cogolla, declarado Patrimonio de la Humanidad por la UNESCO en 1997. Los encuentros que se pondrán de relieve aquí serán singulares por su pertenencia a este objeto artístico concreto, pero no diferirán de los que el historiador del arte podrá experimentar en el ejercicio de su profesión, al catalogar y analizar, tanto las obras de arte como las fuentes documentales, en el estudio de los monumentos de carácter religioso. Por un lado, se comprobará cómo la música adquirirá valores simbólicos y se pondrá de manifiesto en las celebraciones litúrgicas y diversas formas de culto, materializándose, por otro, en hechos y producciones que forman parte de su patrimonio. Dar noticia de su devenir histórico se considera de utilidad para que la ciencia de la música desarrolle sus posibilidades de conocimiento, de modo que el objetivo es llamar la atención de los investigadores sobre materias consideradas merecedoras de un análisis especializado que, obviamente, desborda la disciplina histórico-artística. He dividido las noticias en dos apartados. Uno de carácter iconográfico, dedicado a la presencia de la música en las artes plásticas del monasterio que, una vez revisadas, se ha reducido a la representación de instrumentos musicales en la escultura y pintura que narra la vida de san Millán, concretamente las escenas de pastor y el sueño revelador de su vocación, y en la pintura mural de ángeles músicos en la capilla de Monserrat de la iglesia del monasterio de Yuso. Y otro de índole documental, relacionado con la importancia del coro en la vida monástica, que permitirá conocer las necesidades del convento y la dedicación presupuestaria de la sacristía de la iglesia a las actividades musicales, a través de la confección y uso de libros e instrumentos, así como la visión particular de los novicios que dejaron en los muros de la zona a ellos reservada un buen número de grafitos con inscripciones y escrituras musicales.

La iconografía del santo Emiliano de Berceo (h. 473-†574) no ha recibido un estudio de conjunto pero sí numerosos parciales, centrados en una u otra época o medio artístico. La primera manifestación plástica se encuentra en las placas de marfil que adornaban el arca de sus reliquias, cuya confección, siguiendo el último estudio de José Gabriel Moya, no debió ser anterior a 1080 y debida a manos 
hispanas $^{6}$. La fuente de la narración fue la vida escrita por san Braulio en el siglo VII (entre 635 y 645), de la que se conservaban copias en el monasterio, incluso con iluminaciones ${ }^{7}$. La historia comienza con el origen de la conversión cuando el futurus pastor hominum, erat p(a)st(o)r ouium ${ }^{8}$, como se inscribe en la placa de marfil que representa en la parte inferior la escena del pastor Millán, y es aquí donde el eborario reproduce dos instrumentos musicales ${ }^{9}$ (lám. 1). Uno, el cuerno que está sonando el joven pastor, y sujeta con su mano derecha, y otro, una "cítara" que aparece sobrepuesta a su figura, a la altura del torso, cuyo mango desborda el fondo de la escena y se introduce en la rosca del arco de medio punto sobre columnas, que la enmarca. El texto latino de la hagiografía de san Braulio se refiere a la cítara usada por el pastor para evitar la ociosidad y por ello se labra en la placa, aunque, como ya han puesto de relieve los investigadores del arca relicario, de una forma arbitraria (Bango), o inverosímil (Moya). Sin duda, la fidelidad al texto es más importante que el realismo de la representación, puesto que en este momento artístico impera la expresividad de la forma frente a la verosimilitud del natural, interesando más la presencia del instrumento que su utiliza-

6. Moya Valgañón, J. G., "Arca relicario de San Millán" en Enciclopedia del Románico en La Rioja. Palencia, 2008, vol. II, pp. 600-617. Para él los artífices de los marfiles estarían establecidos en Nájera y serían Simeón, discípulo, y su maestro, "quizá García" (p. 615). Isidro Bango no parece dudar de que la inscripción García se refiere al maestro y considera que la datación no podría ser posterior a 1076, fecha de la muerte de Sancho IV de Navarra, uno de sus valedores (Bango Torviso, I. G., "San Millán. ¡Quién narrara su vida! ¡Quién abrazara su cuerpo!", La edad de un Reyno. Las encrucijadas de la corona y la diócesis de Pamplona. Sancho el Mayor y sus herederos. El linaje que europeizó los reinos hispanos, Pamplona, 2006, pp. 297-351).

7. Bango Torviso, I. B., Emiliano un santo de la España visigoda, y el arca románica de sus reliquias, Salamanca, 2007, pp. 39-41.

8. "Futurus pastor hominum, erat pastor ouium minabatque oves ad uirecta montium et ut mos esse solet pastorum citharam vehebat secum, ne ad gregis custodiam torpor inpediret menten otiosam minusque exercitatione suspensam..." (Vázquez de Parga, L., Sancti Braulionis Caesaragustani episcopi. Vita S. Emiliani, Madrid, 1943, cap. I, 8, 5-20, p. 14).

9. La descripción del inventario elaborado los días 1 a 4 de enero de 1601, con objeto de probar el lugar de la Cogolla como patria de san Millán, describe esta placa: "En la primera que es en un quadro pequeno, de alta un palmo y xeme de ancho, está esculpido en marfil el bienabenturado señor sant Millán, rrelebado en ábito de moço, asentado con una çítara al lado y taniendo él una cornetilla, y delante tiene un rrebano de obejas. Encima desta figura está abierto en el dicho marfil un rrótulo que diçe en letras góticas "futurus pastor ominum erat pastor obium" (Archivo Histórico Nacional, Sección Clero, leg. 3102, cosido, 16 fols., "Milagros, 0.2.1.4, s.f., (en adelante AHN, Sección Clero, leg. 3102); transcrito por Ma Jesús Martínez Ocio y $\mathrm{M}^{\mathrm{a}}$ Cruz Navarro Bretón en el proyecto "Estudio de fondos documentales relativos a los monasterios de Suso y Yuso en San Millán de la Cogolla. 2001" (Logroño, Gobierno de La Rioja, Consejería de Cultura). La consulta progresiva de archivos, junto con estas investigadoras, se prolongó hasta 2007, incrementándose en gran medida el proyecto citado, en el que pueden encontrarse alguna de las fuentes manuscritas citadas en este artículo). Sandoval sigue este texto casi al pie de la letra (Sandoval, P. de, Primera parte de las fundaciones de los monasterios del glorioso padre San Benito... Madrid, 1601, fol. 23 v.). 
ción. Y en esta línea, el artífice elige para ello el cuerno, aerófono más expresivo y habitual a la hora de representar la actividad del pastor. Millán lo sopla, sentado, apoyando en el suelo con su mano izquierda el cayado del revés ${ }^{10}$, frente a tres ovejas que el artífice simula están paciendo, mediante una vegetación esquemática de un tronco y tres hojas, una de las cuales se inserta en la rosca del arco, como hizo con el mango de la cítara en el lado opuesto. El cuerno se dibuja con cierto detalle y riqueza, pues su cuerpo cónico y curvado se adorna con una orla de círculos, distinguiéndose en el otro extremo la separación de la boquilla por una línea". En cuanto a la cítara, presenta una caja acústica aovada con dos agujeros sonoros en forma de letra $D$, enfrentados a cada lado del eje longitudinal y ligeramente por encima del cordal troncopiramidal, liso y con tres agujeros del que parten tres cuerdas que, por razones de la técnica de la labra y el espacio del soporte, se convierten a lo largo del mástil en dos en su unión al clavijero. La parte inferior del cordal se prolonga mediante una incisión hasta el remate de la caja donde se talla un abultamiento saliente ovalado. El clavijero es plano y en forma de rombo con los lados convexos, presentando cuatro agujeros frontales, uno en cada ángulo. La talla es muy simple y algo tosca, al mismo tiempo que de muy pequeño tamaño, ya que la longitud de la cítara alcanzará unos tres centímetros, por lo que no se puede buscar mayor definición de los detalles del instrumento representado. No obstante, sí que se observa la ausencia de ceja o cejuela entre el clavijero y el mástil, así como la talla continua de éste con la caja (lám. 2).

A modo de apunte, pues no es este el objetivo del presente artículo, la representación del cordófono que puede verse en este marfil ${ }^{12}$ podría relacionarse con

10. Esta disposición es frecuente observarla en las representaciones románicas. Así, por ejemplo, en el "Anuncio a los pastores" de las pinturas murales del pórtico de San Isidoro de León; en el capitel de David y Goliat de Santa María de Siones (valle de Mena, Burgos); en otro capitel de Nogal de las Huertas (Palencia), o fuera de España, en una placa de esmalte con la "Aparición del ángel a los pastores" del tesoro catedralicio de Hildesheim (Alemania). Posteriormente, la veremos en la pintura gótica de las tablas de San Millán, procedente del monasterio de Suso (Museo de La Rioja), en las que las imágenes de los instrumentos musicales diferirán en gran medida, y, en la transición al renacimiento, en la escena de la conversión del santo que pinta Alonso Sedano para el retablo mayor de la iglesia de San Millán en Los Balbases (Burgos). El uso del cayado del revés puede tener relación con la práctica de los pastores de separar o retener las ovejas individualmente del rebaño.

11. La representación del cuerno es similar a la que se talla en la placa de marfil de la misma arca en la que se escenifica el milagro del vino, en esta ocasión con función de vasija y no de aerófono.

12. La placa se conserva en el Metropolitan Museum de Nueva York (The Cloisters Collection, 1987.89); fue adquirida por este museo en 1987; mide 16,9 x 7,6 x 0,7 cm; se exhibió en 2006 en la sala Baluarte de Pamplona en la exposición arriba citada La edad de un Reyno, dirigida y comisariada por Isidro G. Bango Torviso, a quien se debe la ficha del catálogo no 119 ("San Millán...", p. 308). Más información sobre los marfiles y su devenir en Sáenz Rodríguez, M., "Los marfiles del monasterio de San Millán de la Cogolla, una obra cumbre de la eboraria en el arte medieval hispano" en Salas Franco, M. P., San Felipe Adán, M. A. y Álvarez Terán, R., 
Lám. 1. Placa de marfil procedente del arca de las reliquias de San Millán, h. 1080 (New York, Metropolitam Museum, The Cloisters Collection, num. 1987.89).
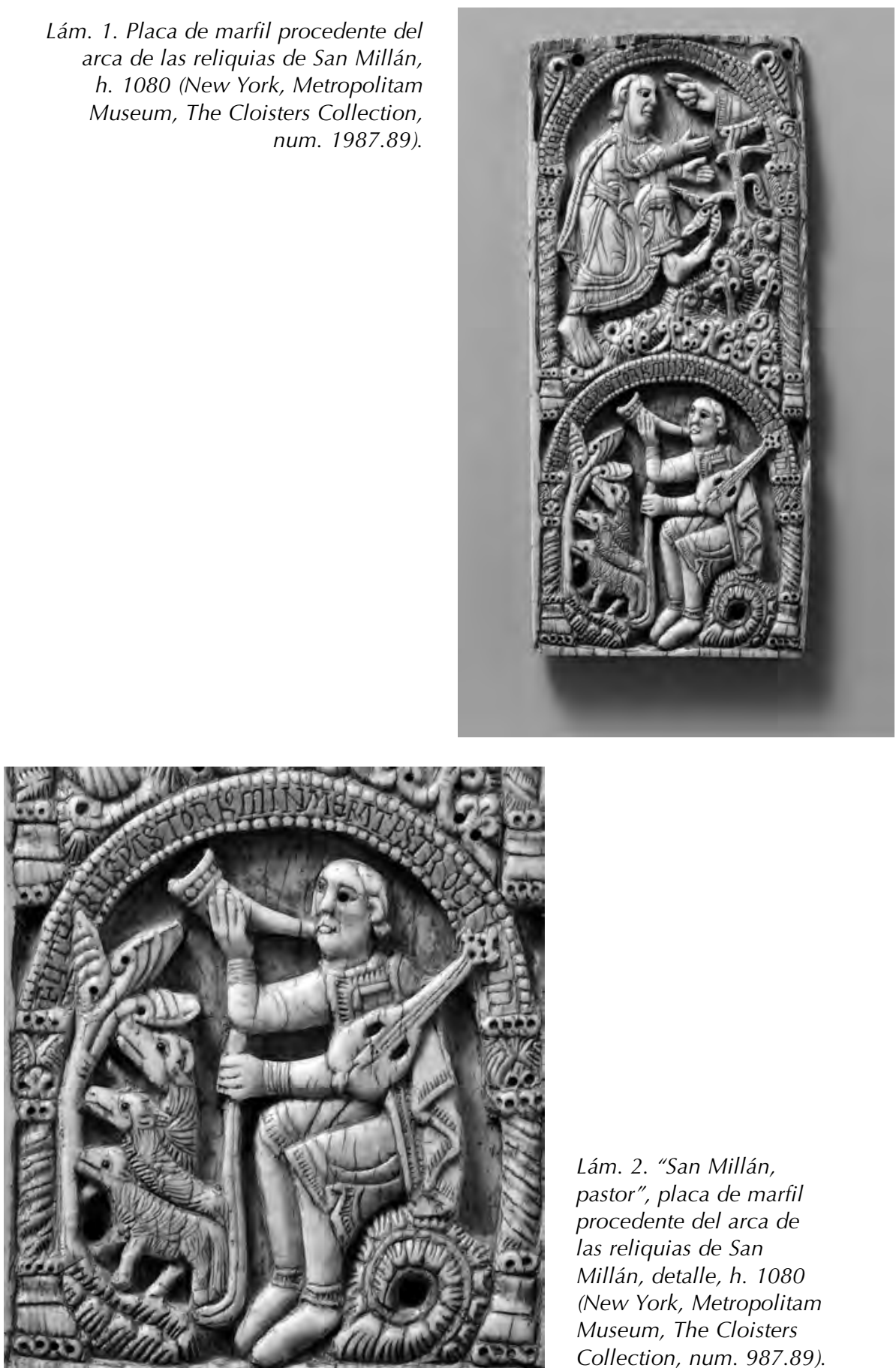

Lám. 2. "San Millán, pastor", placa de marfil procedente del arca de las reliquias de San Millán, detalle, h. 1080 (New York, Metropolitam Museum, The Cloisters Collection, num. 987.89). 
la miniatura coetánea del Beato de San Millán, conservado en la Biblioteca de la Academia de la Historia $^{13}$. En la relativa al Cordero sobre el monte Sión, se acompaña de cuatro ángeles que tocan la vihuela de arco, transposición a la pintura de la cítara aludida en los textos. La forma de la caja es oval y parece ser continua con el mango, las cuerdas son tres y el clavijero romboidal, similar al del marfil. No obstante, en éste no aparece el arco, algo habitual en las imágenes medievales ya que su existencia se presupone, pero su representación se constata desde el siglo X en España. Nos encontraríamos, por tanto, ante una fase evolutiva de los cordófonos de origen bizantino y su transformación en el tipo de fídula oval ${ }^{14}$. De igual modo, el eborario que talló el cuerno que toca Millán parece inspirarse en las propias miniaturas de los escritorios de San Millán y Albelda de la décima centuria. Así, en la decoración de la boca, resaltada por una cenefa en las imágenes, por ejemplo, de la primera trompeta del códice de la Academia de la Historia ${ }^{15}$, que se mantiene en la iluminación, ya románica, de la séptima ${ }^{16}$, o en el adorno de contario que se dibuja en las tubas de las rosas de los vientos de los códices emilianense y vigilano ${ }^{17}$. Pese a las relaciones iconográficas de la eboraria con la miniatura y a la cercanía de los talleres de producción en el ámbito de la Cogo$1 \mathrm{a}^{18}$, la inspiración creativa de los artífices del arca para las imágenes hagiográficas de la vida de san Millán, según san Braulio, se basaron en gran parte en composiciones narrativas de fuentes anteriores que circulaban en los escritorios medievales ${ }^{19}$. Así, la iconografía del pastor con su rebaño se remonta a la imaginería relacionada con Cristo como Buen Pastor, pero la representación concreta

Los marfiles de San Millán de la Cogolla. Su incautación, estancia en Madrid y devolución a La Rioja (1931-1944), Logroño, 2009, cap. 5., pp. 283-465.

13. Biblioteca de la Real Academia de la Historia (en adelante BAH), Códice 33, fol. 177. Ver Silva y Verástegui, S. de, La miniatura en el monasterio de San Millán de la Cogolla. Una contribución a los códices miniados en los siglos XI al XIII. Logroño, 1999, pp. 83-84.

14. Álvarez Martínez, R., "La iconografía musical de los Beatos de los siglos X y XI y su procedencia", Anuario del Departamento de Historia y Teoría del Arte, no 5 (1993), p. 216.

15. BAH, Códice 33, fol. 138 v.

16. BAH, Códice 33, 157 v.

17. Silva y Verástegui, S., Iconografía del siglo $X$ en el reino de Pamplona-Nájera, Pamplona, 1984, pp. 249-250, 268 y 452, láms. 59, 77, 190 y 191.

18. Sobre la relación de las fuentes emilianense (san Braulio y Berceo) con los marfiles del arca y las tablas de San Millán, ver Heras y Núñez, M. A. de las, "La literatura emilianense y el arte medieval riojano" en Lecturas de Historia del Arte. Ephialte. Instituto de Estudios Iconográficos, núm. II, (Vitoria-Gasteiz, 1990), p. 222-226. Otro ejemplo de la inspiración de los relieves de marfil del arca en la miniatura, en Silva y Verástegui, S. de, "Miniaturas inéditas de la 'Vida de San Millán de la Cogolla' en un códice del siglo X", Berceo, no 124, Logroño, 1993, pp. 61-66. Sobre la copia entre códices, ver Álvarez Martínez, R., "Incidencia de una forma de trabajo en la representación de los instrumentos musicales: la copia de códices en la Edad Media", Nasarre: Revista aragonesa de musicología, vol. 23, no 1 (2007), pp. 53-86.

19. Harris, J. A., "Culto y narrativa en los marfiles de San Millán de la Cogolla", Boletín del Museo Arqueológico Nacional, IX (1991), pp. 69-85. 
de Millán sentado y haciendo sonar el cuerno para llamar a las ovejas es poco frecuente y Julie A. Harris la ha puesto en relación con una placa de marfil carolingia (h. 850) que adorna el mango de un flabelo conservado en el Museo Nazionale del Bargello (Florencia), en el que se ilustran las Églogas de Virgilio ${ }^{20}$.

La antigüedad de la representación de los instrumentos de cuerda y de viento en el marfil procedente del arca relicario de san Millán, merece la pena que sea atendida en los estudios de organología sobre el siglo XI, así como el texto de san Braulio del siglo VII, ya que es su hagiografía la que seguirá en el siglo XIII Gonzalo de Berceo al describir a Millán cuando era pastor ${ }^{21}$. Aún cuando se menciona la cítara como instrumento que le acompaña, sabemos que el nombre permanece en la edad Media pero que su forma grecolatina desaparece, pasando a designar cualquier tipo de cordófono ${ }^{22}$. El que representa el marfil emilianense tiene su paralelismo escultórico más próximo en las fídulas ovales que labró, algo más de un siglo después, el maestro Mateo en el Pórtico de la Gloria de Santiago de Compostela ${ }^{23}$.

La iconografía posterior de san Millán ofrece algunas novedades respecto a la representación del cordófono, todas ellas en el ámbito de la pintura y en su mayor parte en relación con la vida de pastor, puesto que en la escultura se optó por la imagen de clérigo, abad, o caballero (al modo de Santiago matamoros), o bien como pastor y presbítero pero sin instrumento musical, como en la imagen de la iglesia parroquial de Oncala (Soria) en la que presenta cayado, un libro y una oveja a sus pies $^{24}$. Del periodo gótico se conservan en el Museo de

20. Harris, J. A., "Scenes from the life of saint aemilian (plaque from reliquary of Saint Aemilian)" en Catalogue 'The art of medieval Spain a.d. 500-1200', New York, The Metropolitan Museum of Art, 1993, n. 125c, pp. 262-263. La placa carolingia se reproduce en el estudio que cita de Peter Lasko de 1972 (ed. española, Arte sacro, 800-1200, Madrid, Cátedra, 1999, p. 81, lám. 52). Así mismo, Harris relaciona la escena superior de la placa en la que se representa al santo subiendo al monte Distercio, después de su adoctrinamiento con san Felices, donde recibe la llamada de Dios, figurado por su mano derecha, con la miniatura del Pentateuco de Ashburnham (siglo VII) y la de un salterio bizantino (siglo X), ambos en la Biblioteca Nacional de París (cod. n. acqu. lat. 2334 y cod. grec. 139). Ver también Lasko, P., op. cit., pp. 67-68, lám. 41 (la "Ascensión de Munich").

21. Dutton, B., "Vida de San Millán de la Cogolla" en Dutton, B. y otros (ed.), Gonzalo de Berceo. Obra completa. Madrid, 1992, pp. 121 y 129, copla 7.

22. Faustino Porras Robles recoge la cítara en la Vida de San Millán por Berceo en "Los instrumentos musicales en la poesía castellana medieval. Enumeración y descripción organológica", Lemir: Revista de Literatura Española Medieval y del Renacimiento, no 12 (2008), pp. 113-136. Por su parte, Ramón Andrés alude a la cítara del texto de Berceo en el vocablo "cítola" (Diccionario de los instrumentos musicales: desde la Antigüedad a J. S. Bach, Barcelona, 2009).

23. Luengo, F., "Los instrumentos del Pórtico" en Villanueva, C. (ed. y coord.), El pórtico..., pp. 84-88.

24. García Gainza, M. C., "San Millán" en Catálogo de la exposición La Ciudad de Seis Pisos. Las Edades del Hombre (El Burgo de Osma, Soria, 1997). Madrid, 1997, cat. 231, pp. 357-358 (obra de la primera mitad del siglo XVIII, atribuida al círculo de Juan Alonso Villabrille y Ron). 
La Rioja (Logroño) desde 1965 dos tablas del siglo XIV (temple, 2 × 1,21 m) procedentes del monasterio emilianense, que formaron parte del retablo mayor de la iglesia del edificio de Suso y que en origen corresponderían a las puertas de un tríptico ${ }^{25}$. En ellas puede observarse la representación de distintos instrumentos musicales en cuatro escenas: una corresponde a la Epifanía, otra a la Coronación de la Virgen, y dos a la vida de san Millán, cuando era pastor y el momento de su conversión. Estos instrumentos fueron analizados por José Antonio Quijera ${ }^{26}$. En la primera escena citada un coro de seis ángeles músicos acompañan a la Virgen con el Niño en actitud de sonar cuatro cordófonos y dos aerófonos (lám. 3). Los instrumentos identificados por Quijera son un rabel con arco (de caja piriforme, abombada, con tapa diferenciada, y clavijero en ángulo recto de tres clavijas); un laud (de caja circular, fondo plano, mástil largo y clavijero en ángulo recto); una vihuela de arco (de caja plana, cuatro cuerdas, puente y grupos de seis y ocho orificios, y mástil con clavijero trilobulado), que responde al modelo de fídula en ocho; un salterio (trapezoidal con dibujos -hispanomusulmanes- $y$ "unas veinte cuerdas"); una gaita troncocónica (de boquiIla diferenciada) y una trompeta, o trompa curva (larga, curvada y con boquilla). La escena de la Coronación está flanqueada por dos ángeles músicos, con sendos rabel y fídula, de forma semejante a los pintados en la Epifanía (lám. 4). Diferente a los anteriores es el cordófono representado en las dos escenas pintadas para la narración de la conversión del pastor Millán, alejadas ya de la iconografía del marfil del arca de sus reliquias. En la primera describe el momento del pastoreo de las ovejas, representando al futuro santo con una pierna arrodi-

25. En la descripción del retablo mayor de Suso, ni el inventario de 1601, ni el texto de Sandoval, hacen mención a estas escenas, relatando las imágenes de otras con cierto detalle, pero siempre referidas a una de las caras de las tablas, y no a su reverso. Ello hace pensar en que para entonces el hipotético tríptico ya había perdido su panel central, habiéndose reutilizado las puertas laterales en un nuevo marco, que no permitiría observar la pintura de la parte posterior. Este enmarque sería anterior al reelaborado un siglo después, con el que llegó al siglo XX y puede verse en fotos antiguas (ver Arrúe Ugarte, B., "Conservación del monasterio de San Millán de la Cogolla, de Suso (La Rioja), durante la Edad Moderna" en Vélez Chaurri, J.J., Echeverría Goñi, P. y Martínez de Salinas Ocio, F. (ed.), Estudios de Historia del Arte en memoria de la profesora Micaela Portilla, Vitoria-Gasteiz, 2008, pp. 521-531).

26. Quijera Pérez, J. A., "Organología medieval riojana: las tablas de San Millán", Revista de Folklore, Fundación Joaquín Díaz, t. 14a, no 161 (1994), pp. 174-180. En general, en los estudios histórico-artísticos de las tablas no se ha prestado atención pormenorizada a este aspecto iconográfico. Ver el trabajo con bibliografía sobre las tablas hasta el momento de Ana M. Galilea Antón, Aportación al estudio de la pintura gótica sobre tabla y sarga en La Rioja. Logroño, 1985, y los de M. A. de las Heras y Núñez, "Las tablas de San Millán de la Cogolla" y M. T. Sánchez Trujillano, "Estudio ambiental de las tablas de San Millán, indumentaria" en Segundo Coloquio sobre Historia de la Rioja (Logroño, Colegio Universitario de la Rioja, 1985), Logroño, 1986, pp. 57-71 y pp. 73-83, respectivamente. La más reciente contribución en Moya Valgañón, J. G., "El arte mueble" en Moya Valgañón, J. G. (dir.), Historia del Arte en La Rioja. Alta Edad Media, Románico y Gótico. III", Logroño, 2006, vol. II, pp. 350-353. 


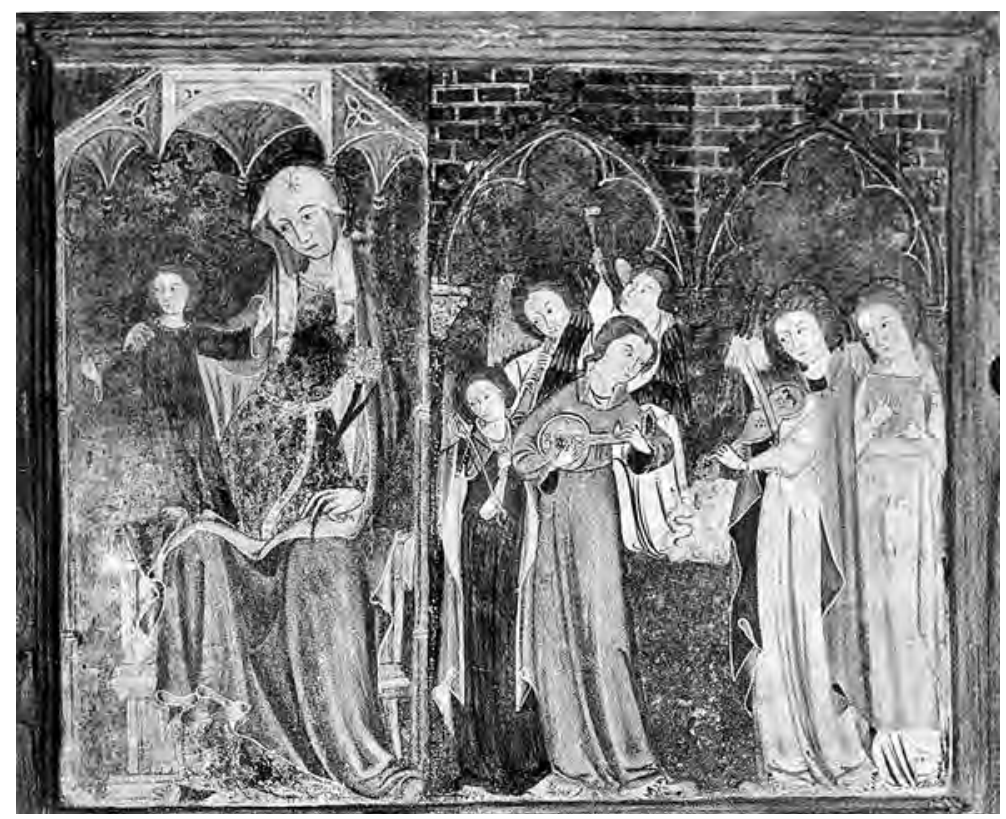

Lám. 3. "Epifanía", Tablas de San Millán, detalle, s. XIV (Logroño, Museo de La Rioja).

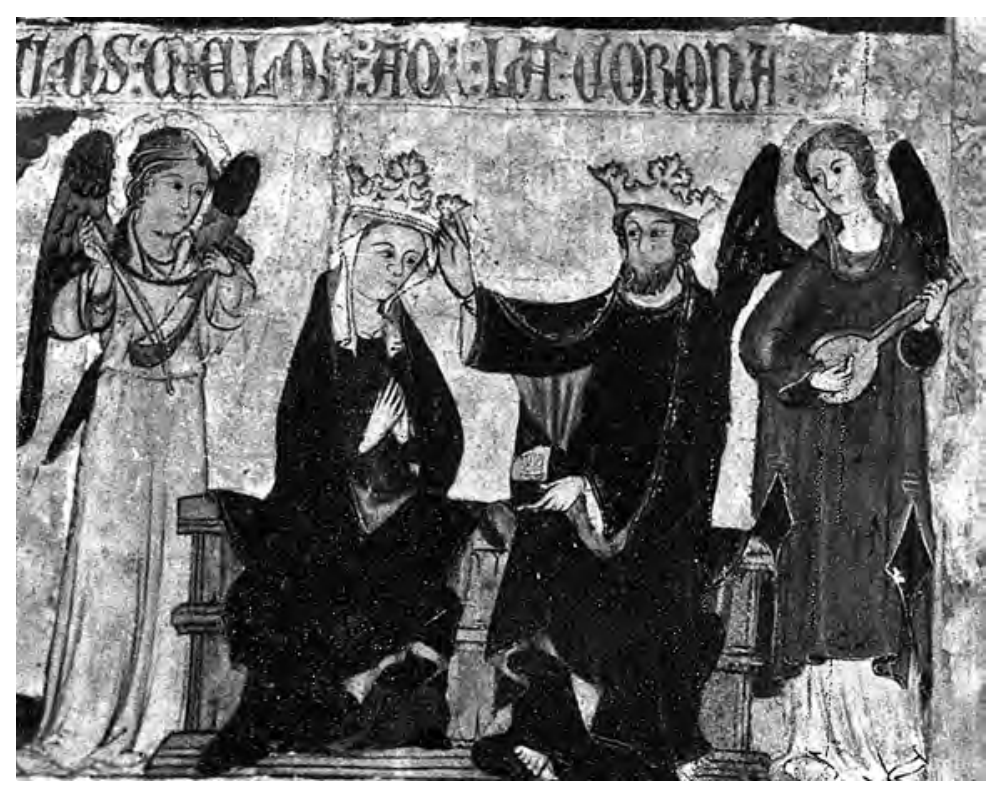

Lám. 4. "Coronación de la Virgen", Tablas de San Millán, detalle, s. XIV (Logroño, Museo de La Rioja). 
Ilada y la otra en ángulo recto, tañendo el instrumento, al lado de un árbol, donde se apoya el cayado del revés y cuelga un talego (interpretado también como un pellejo de vino), y de un perro que parece escucharle con la boca abierta (lám. 5). En la siguiente, el del sueño de Millán en el que el santo recostado, con el cayado del revés en sus manos, el perro y lo que parece el mismo instrumento a sus pies, y el talego pendiente del árbol próximo, recibe la llamada de un ángel que desciende del cielo (lám. 6). En ambas escenas, carentes de inscripción, debido a modificaciones en el marco original, la composición es similar: en el primer término las ovejas pastando, al que sigue la figura de Millán en el lateral izquierdo en una, y en el derecho en la contigua, y finalmente una línea de horizonte en la que sobresalen las formas compactas de unas rocas y dos árboles, recortándose sobre el fondo neutro. Estas escenas comparten con otras de la tabla el enmarque de arcos de medio punto pareados y trilobulados, que apean en columnas laterales y en una ménsula común, con tímpanos simulando sillería pincelada en blanco. En esta pintura, la caja del cordófono representado no es circular u oval, sino poligonal con los laterales convexos, lo que marca su perfil de cinco puntas: dos para los hombros, otras dos en la parte inferior y la quinta en el extremo de la misma. En ella se representan tres dobles líneas de cuerdas paralelas a su eje longitudinal y cuatro orificios en el centro a la altura de los hombros en el de la primera escena, que parecen ser cinco en el cordófono de la segunda. La parte superior de la caja se prolonga en un mástil corto y clavijero en forma de hoz, decorado con una cabeza de dragón. Este tipo de córdófono Quijera lo ha identificado con la cedra, es decir, la cítola (ambos términos derivados del latín cithâra), que el santo utiliza como un laúd, sujetando el mástil con la mano izquierda y un plectro con los dedos de la derecha, aunque en ninguna de las dos imágenes se puede observar el volumen de la caja y si la espalda es plana o presenta más de un aro.

Desconocemos cómo era la imagen de la cítara con la que se representó a san Millán pastor en otro retablo antiguo del monasterio de Suso, que estaba situado sobre la tumba de las tres reinas de Navarra ${ }^{27}$. Otro ejemplo iconográfico de finales del siglo XV, o comienzos del siglo XVI, con el que pueden compararse las obras emilianenses, es la tabla que Alonso de Sedano pintó para la iglesia de San Millán de Los Balbases (Burgos), donde se representa la conversión del santo con el minucioso estilo narrativo hispanoflamenco, ofreciendo la imagen de un cor-

27. "Y encima de dichos sepulcros está vn rretablo mui antiguo de pincel de milagros de señor san Millán, el vno quando siendo pastor guardaba ganado, el qual tiene vna çitera (sic) en la mano y el ganado y perros (-)rres, y en otra parte del dicho rretablo está acostado en su lecho y cercado de demonios quando le quisieron quemar en él con achas encendidas, los quales están executando en sí mesmos, lo qual quisieron haçer en el santo" (AHN, Sección Clero, leg. 3102). Sandoval omite la cítara y detalles (Primera parte..., fol. 23 r.). 


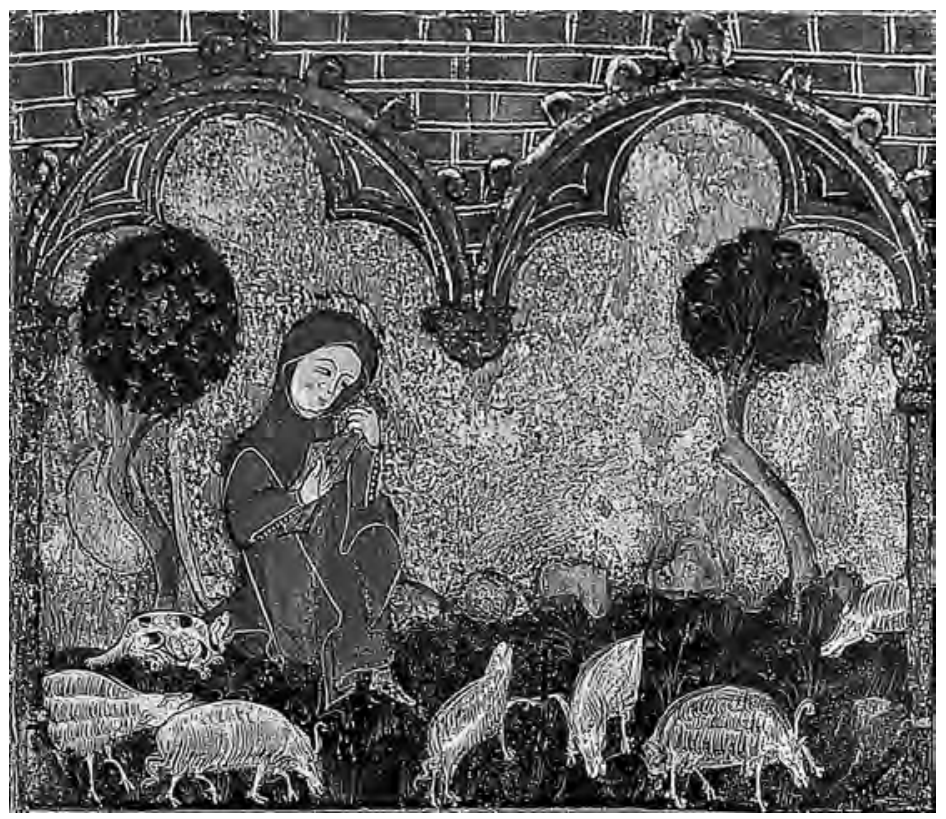

Lám. 5. "San Millán, pastor", Tablas de San Millán, detalle, s. XIV (Logroño, Museo de La Rioja).

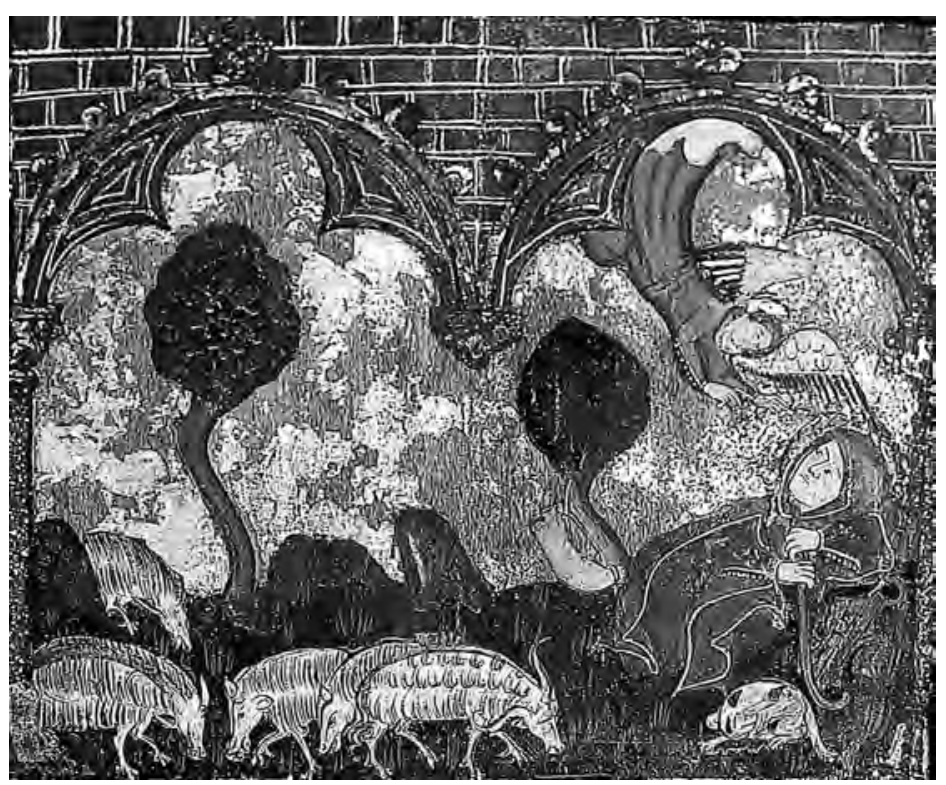

Lám. 6. "El sueño de san Millán", Tablas de San Millán, detalle, s. XIV (Logroño, Museo de La Rioja). 
dófono de arco, con caja periforme, plana, dos agujeros sonoros en C, puente y cordal triangular, mástil diferenciado y clavijero oval de siete trastes ${ }^{28}$.

Por tanto, la imagen de la cítara que acompaña a san Millán pastor cambia de forma desde los periodos mozárabe y románico al final del gótico y este hecho se constará, asimismo, en la edad Moderna, en la que el cordófono adquirirá nuevas variantes iconográficas. Las series pictóricas de la vida de san Millán conservadas en el monasterio de Yuso nos remiten a los siglos XVII y XVIII. Las traducciones del texto latino de san Braulio por parte de Sandoval, que utiliza Martínez ${ }^{29}$, y de Mecolaeta ${ }^{30}$ se deciden por denominarlo rabel, instrumento con el que los zagales se entretenían durante el pastoreo, tal y como se describe en el diccionario de Covarrubias (1611) y se mantiene en el de Autoridades (1737), de forma similar al laud y compuesto de tres cuerdas ${ }^{31}$. El dominio y destreza en su manejo por el pastor Millán será transformado por una visión celestial en "instrumento de letras", elevando su ánimo a la contemplación divina, como explica su hagiografía. En el siglo XIX fray Toribio Minguella retomará el término cítara, siguiendo muy de cerca la traducción de Sandoval ${ }^{32}$. Las dos escenas que veíamos en las tablas góticas se reúnen en la iconografía moderna en una sola - "El sueño de San Millán"- y, dependiendo de las necesidades o imperativos de la ubicación, podrá unirse a ella la visita a san Felices.

28. Puede verse en "Vida y milagros: Historia gráfica del señor san Millán", Patrimonio. Fundación del Patrimonio Histórico de Castilla y León, no 36 (2009), pp. 12-19.

29. "Y como es costumbre de pastores, lleuaba consigo vn rabel, para que asistiendo a la guarda de su ganado, no impidiese la flojedad el alma ociosa, y no ocupada en algún ejercicio. Y como llegase al lugar ordenado por Dios, le vino vn sueño del cielo (porque aquel artífice de los puros corazones, con grande artificio suele hazer su officio) y la ocupación del rabel mudó en instrumentos de letras, y el alma de vn ganadero, la levanta a contemplaciones soberanas. En despertando trató de otra vida celestial, y dexando los campos, caminó para el yermo" (traducción de Sandoval editada por Martínez, M., Apología por San Millán de la Cogolla, Patrón de España. Madrid, 1643, fols. 9-10).

30. "Llevaba consigo vn rabel, como usan ordinariamente los zagales, para que ejercitándose en tañer el instrumento impidiesse feas ociosidades al ánimo, y estuviesse despierto su cuidado para las precisas funciones de su oficio. Pero llegando un día al sitio, a donde suavemente le conducía el Cielo (que el Artífice soberano haze sus obras con incomprensible estudio) se echó a dormir, y fue su dulce sueño vna visión celestial; pues convirtiéndose en una sabiduría profundísima la destreza en el manejo de aquel pastoril rabel, se halló el ánimo de aquel humilde zagal elevado repentinamente a la alta cumbre de la divina contemplación" (Mecolaeta, D., Desagravio de la verdad en la Historia de San Millán. Madrid, 1724, fols. 17-18).

31. Cabe citar aquí el análisis de instrumentos relacionados con el pastoreo de carácter arcádico en el siglo XVI de Berrio Martín-Retortillo, P., "Instrumentos musicales en 'El pastor de Fílida", Dicenda: Cuadernos de Filología Hispánica, no 12 (1994), pp. 11-18.

32. Minguella, T., San Millán de la Cogolla. Estudios Histórico-Religiosos acerca de la Patria, Estado y vida de San Millán. Madrid, 1883. Traducción íntegra publicada en "Vida y milagros del gloriosísimo San Millán, presbítero y confesor de Cristo" en San Millán de la CogoIla en su XV centenario, 473-1973. Logroño, 1974, pp. 19-51 (núm. Monográfico del Boletín de la provincia de San José. Agustinos Recoletos). 


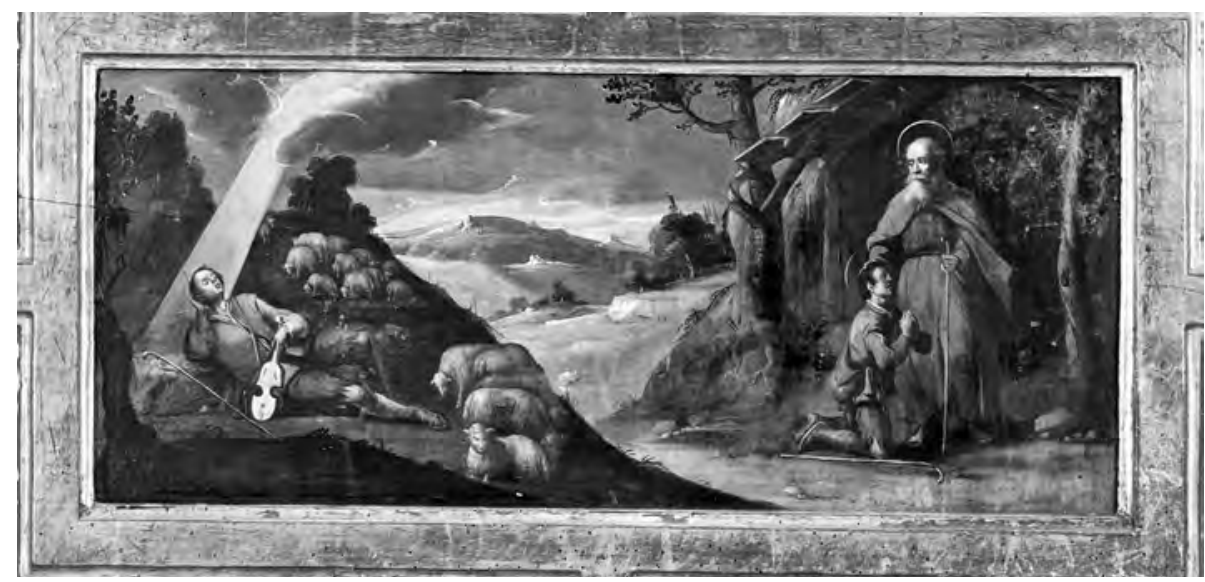

Lám. 7. "El sueño de san Millán y visita a san Felices", atribuido a Pedro Ruiz de Salazar, h. 1642-1644, tabla del retablo de San Millán (San Millán de la Cogolla, monasterio de Yuso, iglesia).

Es el caso del retablo de San Millán que da nombre a la capilla sur de los pies de la iglesia de Yuso. En la pequeña tabla oriental del banco $(26$ × $62 \mathrm{~cm})$ Pedro Ruiz de Salazar pintó, hacia 1642-1644, las dos escenas citadas, ocupando el sueño la mitad izquierda. En ella el pastor dormido sujeta con la mano izquierda el alargado mástil de un cordófono, (interpretado en las descripciones como un rabel), dibujado con precisión y en posición casi frontal, de modo que la luz de su caja se resalta frente al contraluz de la vegetación del primer término ${ }^{33}$ (lám. 7). Este interés por el detalle del instrumento musical lo vemos en otra obra atribuida, asimismo, a este pintor (hacia 1658-1659), que forma parte de una serie de cuatro lienzos de gran formato (3,79 x 1,95 m aprox.), sobre la vida de san Millán, que colgaban hasta los años treinta del siglo XX de los muros norte y sur de la nave crucero de la iglesia ${ }^{34}$. En el pasaje del sueño, el pintor vuelve a reproducir el instrumento musical, de igual modo descansando sobre el cuerpo del zagal y dibujado de frente (lám. 8). La caja es de perfil similar, de hombros caídos y pronunciadas escotaduras centrales, pero difiere en la disposición de los orificios resonadores en forma de $f$, que en la tabla anterior se dibujan en la parte superior y en ésta, en la central; en ambos parece apreciar-

33. Gutiérrez Pastor, I., Catálogo de pintura del monasterio de San Millán de la Cogolla, Logroño, 1984, p. 103, cat. no 92.

34. Gutiérrez Pastor, I., Catálogo..., pp. 101-102, cat. no 89. En la actualidad han sido restaurados tres de ellos y colocados en la escalera real, habiéndose perdido en buena parte el cuarto, lo que fue una de las razones para no devolverlos a su lugar de origen en la última restauración. 

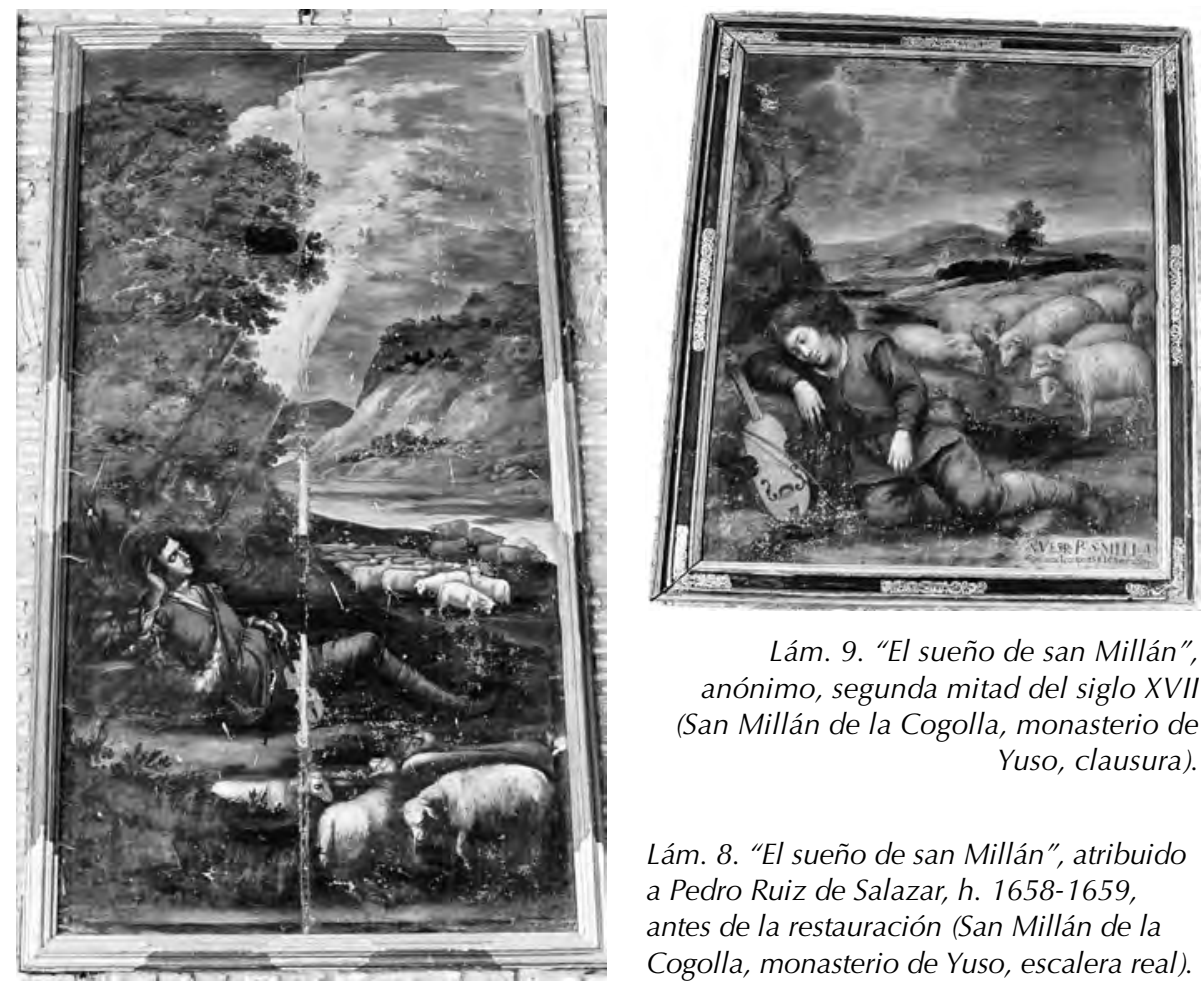

Lám. 9. "El sueño de san Millán", anónimo, segunda mitad del siglo XVII (San Millán de la Cogolla, monasterio de Yuso, clausura).

Lám. 8. "El sueño de san Millán", atribuido a Pedro Ruiz de Salazar, h. 1658-1659, antes de la restauración (San Millán de la Cogolla, monasterio de Yuso, escalera real).

se otro agujero sonoro central, así como el puente y el cordal. El mástil es también recto y el clavijero rematado en voluta, con lo que parecen dos trastes en el anterior, y no pudiéndose observar su número en el lienzo por ser la zona que sujeta la mano izquierda del santo. En otro cuadro del mismo tema de autor anónimo, conservado en la clausura monástica, se pinta el cordófono apoyado en una roca al lado del pastorcillo dormido, de caja de hombros caídos, escotaduras resaltadas, y ligeramente abombada, con tres cuerdas, los orificios en $f$ en la parte inferior de la caja, flanqueando otro ovalado en el centro; el arco cruza el cuerpo del instrumento, proyectando su sombra sobre él ${ }^{35}$ (lám. 9).

Los tres ejemplos de cítara de arco pintados se asemejan a otras representaciones de la viola renacentista, versiones de la viola bastarda, o la de gamba, derivadas de la fídula medieval antes comentada, todas ellas variantes de cordófonos compuestos del tipo laúd con mástil. Tal vez el pormenor de que se pinten

35. Segunda mitad del siglo XVII, óleo/lienzo, 1,10 x 0,91 m; inscripción en el ángulo inferior derecho: "NUESTRO Pe. S. MILLAN/ quando le despertó el Espíritu Santo". Ismael Gutiérrez Pastor lo atribuye a escuela española (Catálogo..., p. 131, cat. oำ194). 
con tres cuerdas indica la estrecha relación entre la traducción de la Vida del santo de la época, con la definición de los diccionarios contemporáneos y, sin duda, con el uso y cercanía de un mismo tipo de instrumento de cuerda, identificado con el rabel. Los mismos caracteres se han podido observar en una pintura mural sacada a la luz en la última restauración de la iglesia del monasterio de Yuso ${ }^{36}$ (lám. 10). Se trata de la pintura aparecida en el medio punto del muro sur, bajo la cúpula, de la capilla de San Agustín o capilla norte del presbiterio de la iglesia del monasterio de Yuso, que se publica ahora por primera vez. En ella se representa el sueño revelador del joven pastor de ovejas en el lado oriental del muro, habiéndose perdido la zona opuesta (lám. 11). Forma parte de un ciclo iconográfico con escenas de la vida de san Millán y de san Benito con los que se decoraron los muros de esta capilla, tras su adquisición en 1690 por fray Benito de Salazar, quien había sido abad de San Millán (de 1661 a 1665 y de 1673 a 1677), y obispo de Barcelona (desde 1682 hasta su muerte el 28 de diciembre de 1692). Para ella encargó un nuevo retablo dedicado a san Benito, patrón de la orden, la decoración mural, rejas de cierre y su monumento funerario. Al instalarse la orden de Agustinos Recoletos en el monasterio de Yuso en 1878, la capilla se transformó en un espacio dedicado al fundador de la nueva orden, san Agustín de Hipona, reemplazándose la imaginería benedictina del retablo por otra agustiniana. Las pinturas murales fueron cubiertas en 1790, dado el mal estado que presentaban, según acuerdo del Consejo del convento ${ }^{37}$. El ocultamiento total debió suceder en la pintura del conjunto de la iglesia llevada a cabo en $1883^{38}$. Los desprendimientos con los que llegó al siglo XXI hicieron necesaria la eliminación de esta última capa, descubriéndose bajo ella entre 2009 y 2010 la pintura original de finales del siglo XVII. Su autor, José de Salazar, sobrino del obispo fundador de la capilla, no era muy hábil en el dibujo de la figura humana, pero trató de que el escorzo del santo recostado se visualizara desde abajo con cierta naturalidad, y de que el cordófono, como atributo iconográfico, fuera patente. Así, no lo coloca a su lado o apoyado en el suelo, sino frontal y en lo alto, en posición transversal a la rama de un árbol, bajo el que duerme el pastor, posición realmente inverosímil. Se distingue su caja, de hombros caídos y escotaduras semicirculares, aunque no se puede apreciar su parte posterior, con dos orificios en $\mathrm{f}$, flanqueando otro central y tres cuerdas, un mástil diferen-

36. Proyecto de restauración integral de la iglesia, 2005-2011, convenio Fundación Caja Madrid, Fundación San Millán de la Cogolla y Orden de Agustinos Recoletos; ejecución y dirección de obra, Óscar Reinares Fernández; supervisión del Proyecto Cultural y dirección del Plan de comunicación y difusión: Gabriel Morate Martín; empresa adjudicataria, UTE San Millán (COMSA-INSITU).

37. AHN, Sección Clero, libro 6082 (Libro de Actas del Consejo, 1774-1819), s.f.

38. Archivo Parroquial San Millán (en adelante APSM), Legajo $6^{\circ}$, Libro de Cuentas de Fábrica de la iglesia parroquial de San Millán de la Cogolla, 1852-1886, y otros documentos variados, fols. 32 v.-33 r. 


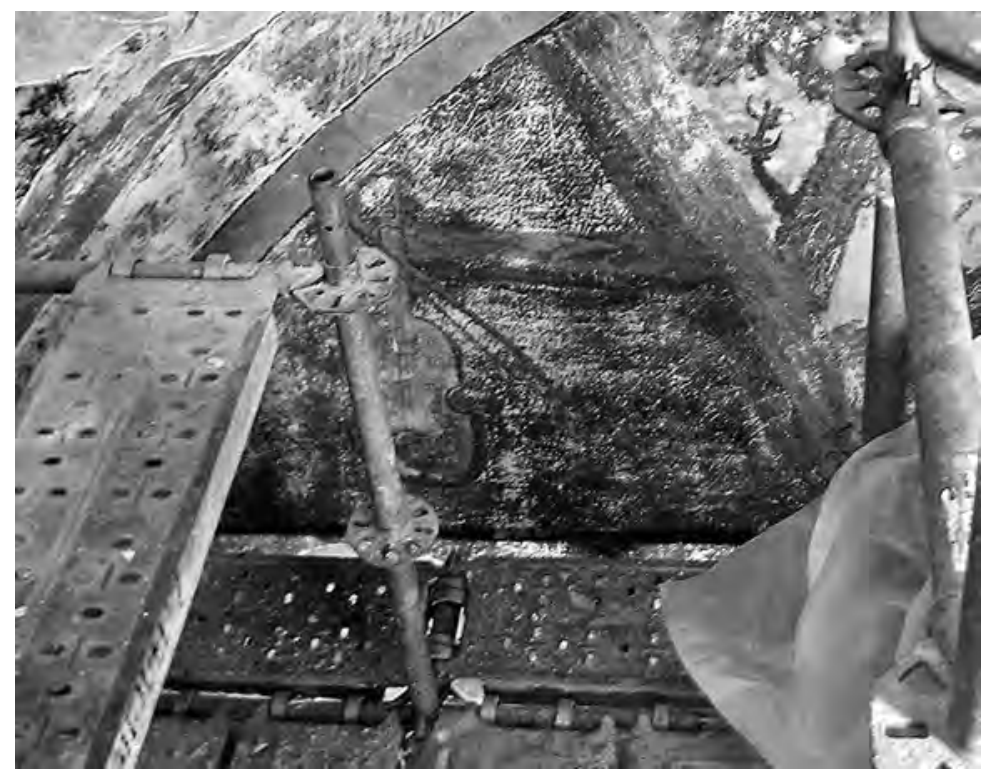

Lám. 10. Cordófono de la pintura mural "El sueño de san Millán", descubierta en el proceso de restauración de la capilla de San Agustín, en 2009 (San Millán de la Cogolla, monasterio de Yuso, iglesia).

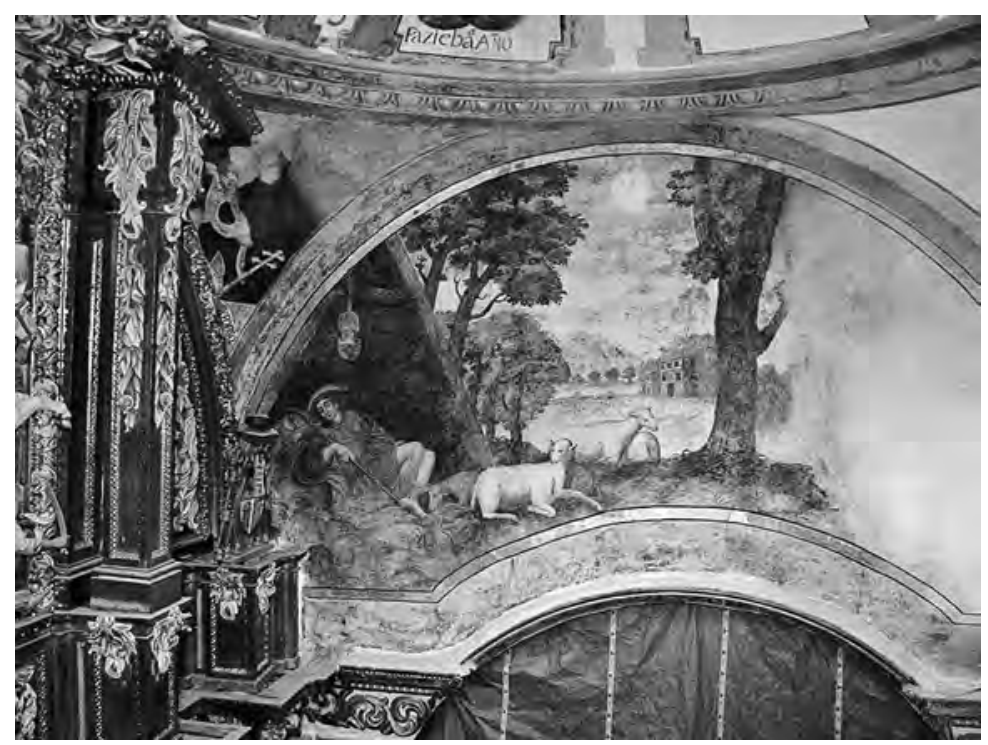

Lám. 11. "El sueño de san Millán", José de Salazar, h. 1692, muro sur, capilla de San Agustín (San Millán de la Cogolla, monasterio de Yuso, iglesia; foto Ó. Reinares, 2010). 
ciado de sección recta y remate en voluta con tres trastes, que parecen tener resaltes laterales, y el arco que lo cruza suspendido. Tal vez, Salazar se fijó en el cuadro anónimo comentado arriba, ya que lo reproduce con cierta fidelidad.

El mismo pintor decoró la capilla que, tras la de san Benito, el obispo dedicó a la Virgen de Monserrat. En las pechinas de la cúpula pintó cartelas de roleos vegetales con medallones ovales de laurel enmarcando ángeles que tañen instrumentos musicales: tres de cuerda (lira, laud y rabel) y uno de viento insuflado por un extremo (gaita, flauta o chirimía) (lám. 12). Este último tiene forma cónica, embocadura resaltada y no se distinguen los orificios de digitación, aunque los dedos del ángel parecen señalarlos (lám. 13). La lira presenta caja semicircular en la parte inferior, rematada en volutas laterales en la superior y travesaño recto, que se prolonga en un mástil que sujeta el ángel con la mano izquierda, mientras que con la derecha toca las siete cuerdas pintadas en el cuerpo (lám. 14). El laud es de caja oval de tapa plana y espalda abombada, con agujero sonoro circular, cinco cuerdas y largo mástil, con clavijero recto y trastes frontales (lám. 15). El otro cordófono es similar al pintado en la capilla de San Agustín, por lo que lo denominamos, asimismo, rabel (lám. 16); tiene caja con escotaduras, dos agujeros en $\mathrm{f}$, otro central, cordal destacado y tres cuerdas; el ángel lo frota con un arco que sujeta con la mano derecha y no se representa la prolongación en el mástil por los límites del marco.

El último ejemplo de cordófono lo ofrece una de las pinturas de la serie de veinticinco lienzos de formato semicircular que sobre la vida de san Millán pintó José Bejés para el claustro alto del monasterio de Yuso ${ }^{39}$ (lám. 17). Si en todas las pinturas mencionadas la escena del sueño de san Millán permite al pintor demostrar sus dotes para el paisaje bucólico pastoril, es en la obra Bejés donde se manifiesta ampliamente con el esplendor rococó que caracteriza su estilo, frente al anterior comedimiento barroco. El pintor ha dispuesto en el primer término de la composición al pastorcillo dormido, recostado, con un instrumento de cuerda a la altura de la cabeza en sentido perpendicular a la diagonal de su cuerpo. Detrás de ello y del árbol a contraluz que marca el plano, se extiende hacia el fondo y los lados el paisaje, con las ovejas paciendo y un cielo de repletas nubes que se abren en gloria para dar paso al rayo divino. Este lienzo fue el elegido por Bejés para estampar su firma: "BEGES FET". La obra se la encargó el abad fray Anselmo Petite (1777-1781), quien solicitó permiso para ello al General de la Orden el 25 de mayo de $1779^{40}$. El cordófono que pinta Bejés se diferencia de los ejemplos comentados del siglo XVII. La caja no presenta escotaduras, es oval y algo abombada, con lo que parece más de un aro; tiene agujero sonoro circular y cinco cuerdas y se prolonga de forma continua

39. Ver Gutiérrez Pastor, I., Catálogo..., pp. 59-60, cat. no 15.

40. AHN, Sección Clero, Lib. 6082, s.f. 


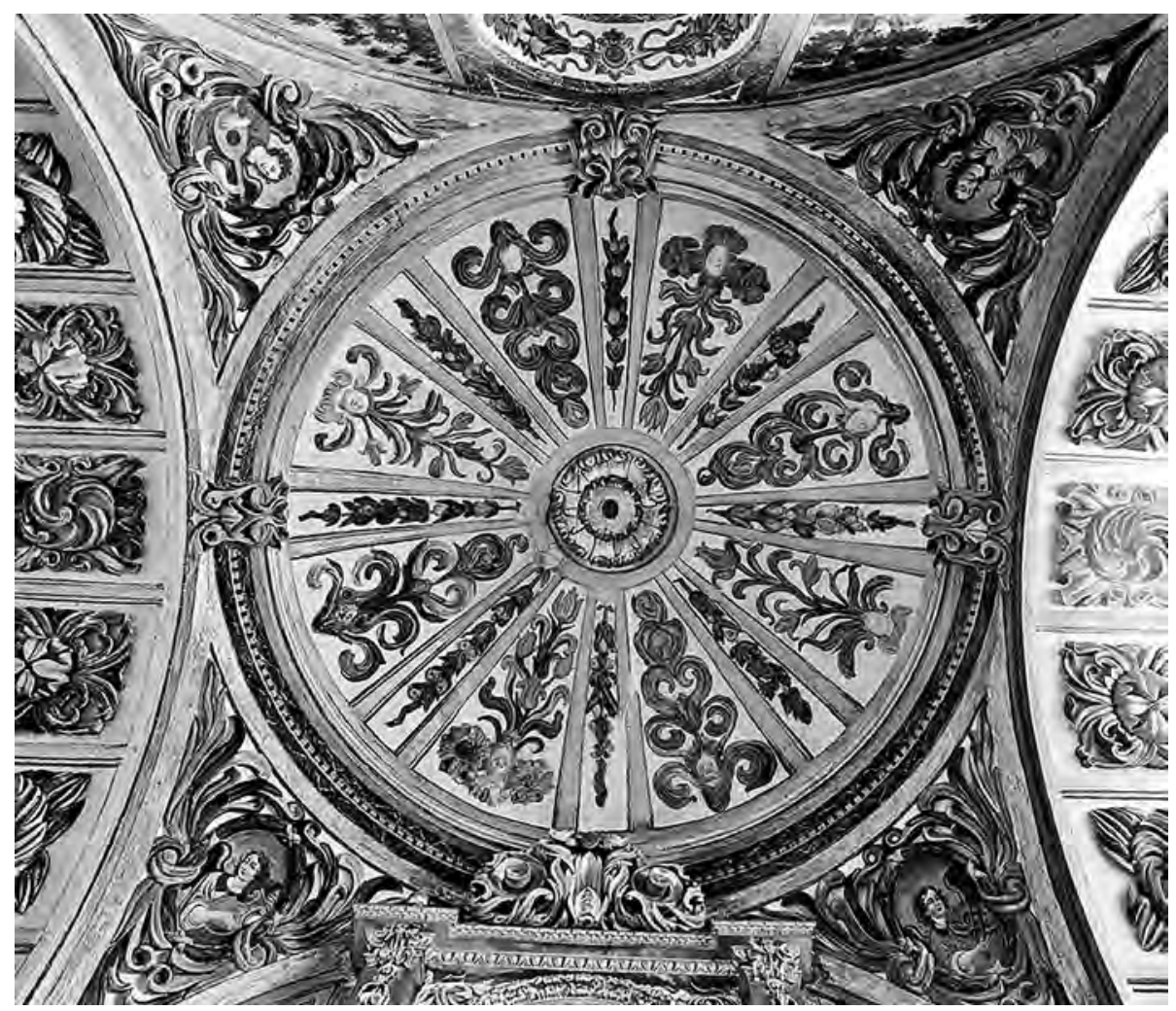

Lám. 12. Cúpula de la capilla de Monserrat, después de la restauración de 2011 (San Millán de la Cogolla, monasterio de Yuso, iglesia; foto Artempus).

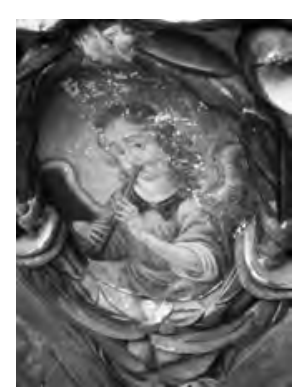

Lám. 13.

"Ángel con

instrumento de viento".

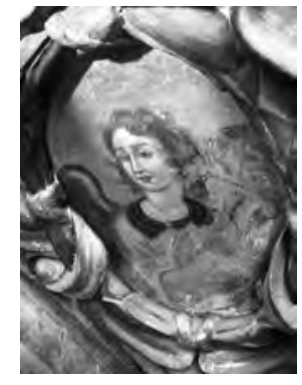

Lám. 14.

"Ángel con lira".

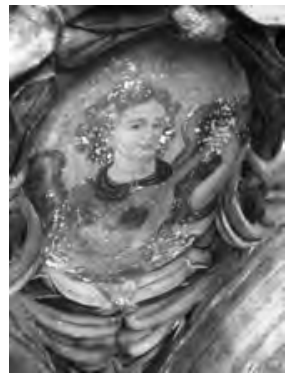

Lám. 15.

"Ángel con laud".

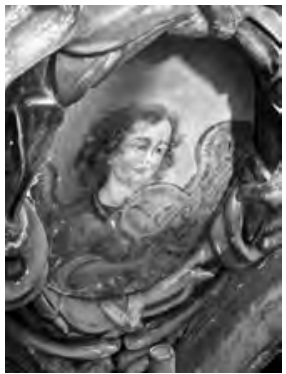

Lám. 16.

"Ángel con rabel".

Pinturas murales de José de Salazar, 1692, pechina de la cúpula de la capilla de Monserrat, antes de la restauración de 2011 (San Millán de la Cogolla, monasterio de Yuso, iglesia). 


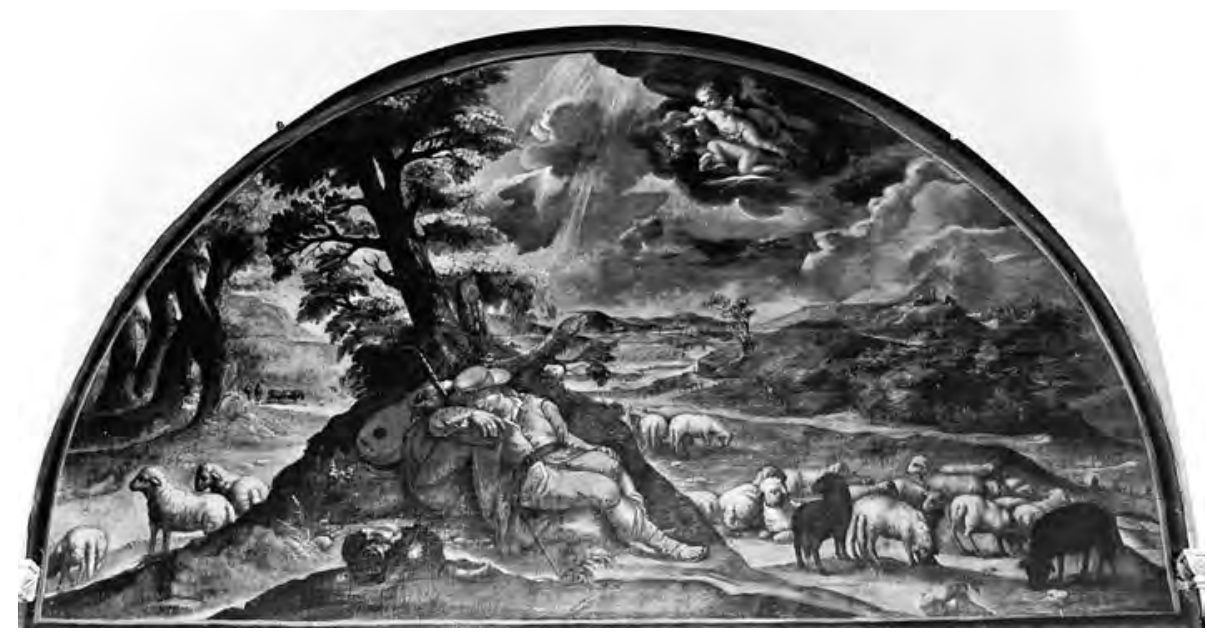

Lám. 17. "El sueño de san Millán", José Bejés, 1779-1781 (San Millán de la Cogolla, monasterio de Yuso, claustro alto).

en el mástil recto, en el que se diferencia el clavijero pero no se definen bien los trastes. Tal vez este instrumento musical se adapte mejor, que al anteriormente descrito como rabel, a la denominada vihuela en los diccionarios de la época, que en el siglo XVIII significaba lo mismo que guitarra (Dic. Autoridades, 1780). En cualquier caso, las imágenes de cordófonos que las artes plásticas crearon en el monasterio de San Millán de la Cogolla para simbolizar las circunstancias de la llamada a la santidad de quien motivó su fundación, son manifestación expresa de la cítara y su variada iconografía desde la alta edad Media hasta el siglo XVIII ${ }^{41}$. Los especialistas en musicología pueden encontrar aquí un repertorio histórico para su mejor definición.

Pasando al segundo apartado propuesto, debemos adentrarnos en el ámbito de una actividad primordial en la vida monástica: el coro y la celebración de los oficios divinos. No podemos detenernos, pese al gran interés, en los aspectos constructivos de los dos coros que tanto el edificio de Suso, como el de Yuso, mantuvieron, uno en el espacio de la iglesia y otro en alto, eliminados definitivamente los del primero en la intervención de Íñiguez Almech de $1934^{42}$, y con-

41. Santiago Sebastián en su día puso en relación la presencia iconográfica del rey David tocando el arpa, inspirada en la figura de Orfeo pulsando la lira y ésta en la del Buen Pastor, en la pintura mural de la iglesia de Orihuela del Tremedal con el pasaje de la vida de pastor de san Millán, en "El programa iconográfico de San Millán de la Cogolla, en Orihuela del Tremedal (Teruel)", Traza y Baza, no 3 (1975), p. 105.

42. Ver su reforma a comienzos del siglo XVIII en Arrúe Ugarte, B., "Conservación...", pp. 527-529. 
servados afortunadamente en el segundo, incluida la vía sacra de comunicación entre el altar mayor y el coro bajo, las rejas, sus correspondientes sillerías alta y baja, y facistoles para el manejo de cantorales, bienes muebles realizados entre 1640 y 1740, aproximadamente ${ }^{43}$ (lám. 18). No debe olvidarse que la iglesia del monasterio de Yuso nunca ha dejado de cumplir funciones de parroquia de la localidad, por lo que el Ilamado trascoro, o antecoro, con sus altares y púlpito era la zona reservada a los fieles, los cuales podían asistir a los oficios del coro bajo y altar mayor a través de su puerta central, como era habitual en las órdenes monásticas ${ }^{44}$ (lám. 19). No son muchas las noticias que nos informan del uso del coro, tal vez porque no fue ese el objeto de nuestro trabajo cuando consultamos las fuentes manuscritas, pero sí tenemos un testimonio relevante en los grafitos del noviciado conventual que nos indica cómo para los novicios las actividades en el coro eran vitales en su formación. Veamos en primer lugar los datos sobre libros e instrumentos, para concluir con las aportaciones de los grafitos, tal vez de mayor curiosidad e interés para la musicología por su novedad.

La primera noticia que podemos destacar en relación con el canto en la iglesia emilianense, al margen de lo que se pueda rastrear en la diplomática medie-

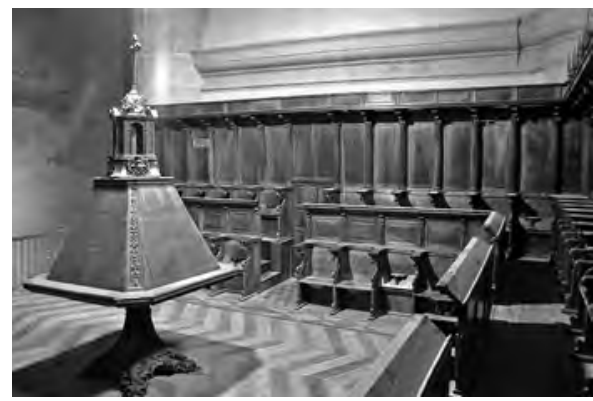

Lám. 18. Coro alto, antes de la restauración de 2011 (San Millán de la Cogolla, monasterio de Yuso, iglesia).

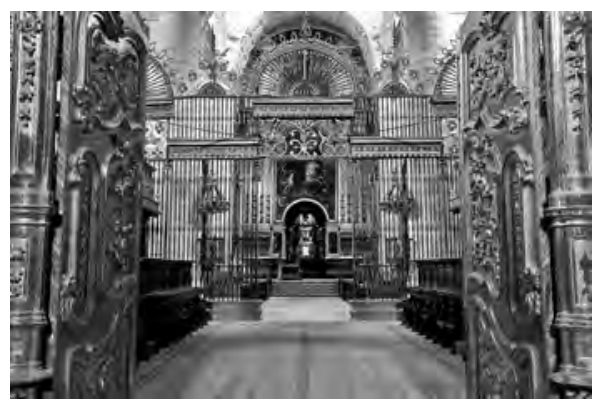

Lám. 19. Coro bajo y vía sacra desde la puerta del antecoro (San Millán de la Cogolla, monasterio de Yuso, iglesia; foto Artempus).

43. Datos histórico-artísticos en Arrúe Ugarte, B. y Martínez Glera, E., “Valoración del patrimonio arquitectónico del monasterio de San Millán de la Cogolla de Yuso (La Rioja)", Berceo, 133 (1997), pp. 111-140, y Arrúe Ugarte, B., “Apuntes sobre patronazgo y conservación del patrimonio artístico del monasterio benedictino de San Millán de la Cogolla". Actas de las VI Jornadas de Arte y Patrimonio Regional. Los monasterios de San Millán de la Cogolla. Logroño, 2000, pp. 117-165.

44. Sobre la función y ubicación del coro ver Navascués Palacio, P., Teoría del coro en las catedrales españolas. Madrid, 1998. 
val $^{45}$, nos lleva al siglo XIII, cuando don Íñigo, abad del monasterio, dotó en 1269 el altar de San Juan con una lámpara y en 1274 una capellanía con capeIlán que cantase misa cada día en honor a san Millán (domingo, lunes, miércoles y viernes) en el altar mayor, y a san Felices (martes y jueves) en el altar de San Juan, donde estaban sus respectivas reliquias ${ }^{46}$. La celebración de misas cantadas sería frecuente y, obviamente, se prolongaría en el tiempo. No obstante, cabe referir la orden expresa de 1734 del General de la Congregación de San Benito de que se cantase misa los días de fiesta y festividades de Nuestra Señora en el santuario de Suso, atendiendo a la veneración que se debía tener en él. Desde el siglo XI se acostumbraba a llevar al edificio de Suso sobre andas las arcas relicario de san Millán y san Felices, costumbre que se mantenía en el siglo XVII, celebrando fiestas con danzas, suiza y colaciones ${ }^{47}$.

Un capítulo importante del presupuesto del monasterio se centró durante años en la composición de los libros del coro, al menos durante el periodo en el que se han conservado Libros del gasto, lo que viene a indicar que debió ser tarea habitual en la medida de las posibilidades económicas y del uso y desgaste que de ellos se hacía. Del siglo XVI, el padre Olarte ha dado a conocer el concierto de 1512 con el bachiller Francisco López, clérigo de Palencia, para la copia de un cantoral, escrito, pintado, iluminado y solfado ${ }^{48}$. En el siglo XVII se documentan arreglos en estos libros, en los que se llevan a cabo en 1689, 1690, 1691 y 1715 diferentes labores de restauración: encolado, reparación de tablas de madera y colocación de cantoneras, tachuelas, cadenillas, herrajes, lizas y cordeles $^{49}$. A partir de 1729 se constata la ejecución del archivo de can-

45. El padre Juan Bautista Olarte, archivero y bibliotecario del monasterio, documenta un "Garsea cantor" en 1050, y el "cantor Munio" en 1146 en Manuscritos de San Millán de la Cogolla (759-1900). Reseña y anotación. Monasterio de Yuso, 2009, formato CD, núm. 289 y núm. 900.

46. Olarte, J. B., Manuscritos..., núm. 1276 y 1288 (el monje, o misacantano, obtendría una torta o dinero, a elegir). Transcripción en García Turza, C. y García Turza, J., Una nueva visión de la lengua de Berceo a la luz de la documentación emilianense del siglo XIII. Logroño, 1996, doc. 60 y 62 .

47. Sobre misas cantadas y celebraciones en Suso ver Arrúe Ugarte, B., "Conservación...", pp. $522-523$.

48. Olarte, J. B., Manuscritos..., núm. 1969. Entre diciembre de 1690 y diciembre de 1691 la sacristía de la iglesia anotó gastos de materiales (tinta, grasilla, caparrosa, pergamino) para la confección de un libro nuevo de oficios que hacía el padre Félix Gil, cuya encuadernación se llevó a cabo en Logroño en 1692, incluidas tablas, baqueta y cantoneras (AHN, Sección Clero, Secular-Regular, Libro 6035 , fols. 70 r.-71 r., 72 v. -73 v. y $74 v .-75$ r.).

49. AHN, Sección Clero, Secular-Regular, Libro 6035 ("Libro del gasto que se hace en las obras de este Real Monasterio de San Millán de la Cogolla", 1675-1769), fol. 67 r., 68 r. y v., 72 v., y cuentas s. f. de 30/06/ a 29/12/1715 en las que, por ejemplo, se anota el gasto de 148 reales de tablas, clavos, cordeles, tachuelas, manillas, registros de hierro y cantoneras utilizados en la composición. En 1725 se compró un libro de coro a la casa de Valvanera por 250 reales (AHN, Sección Clero, Secular-Regular, Libro 6035, s.f.). 


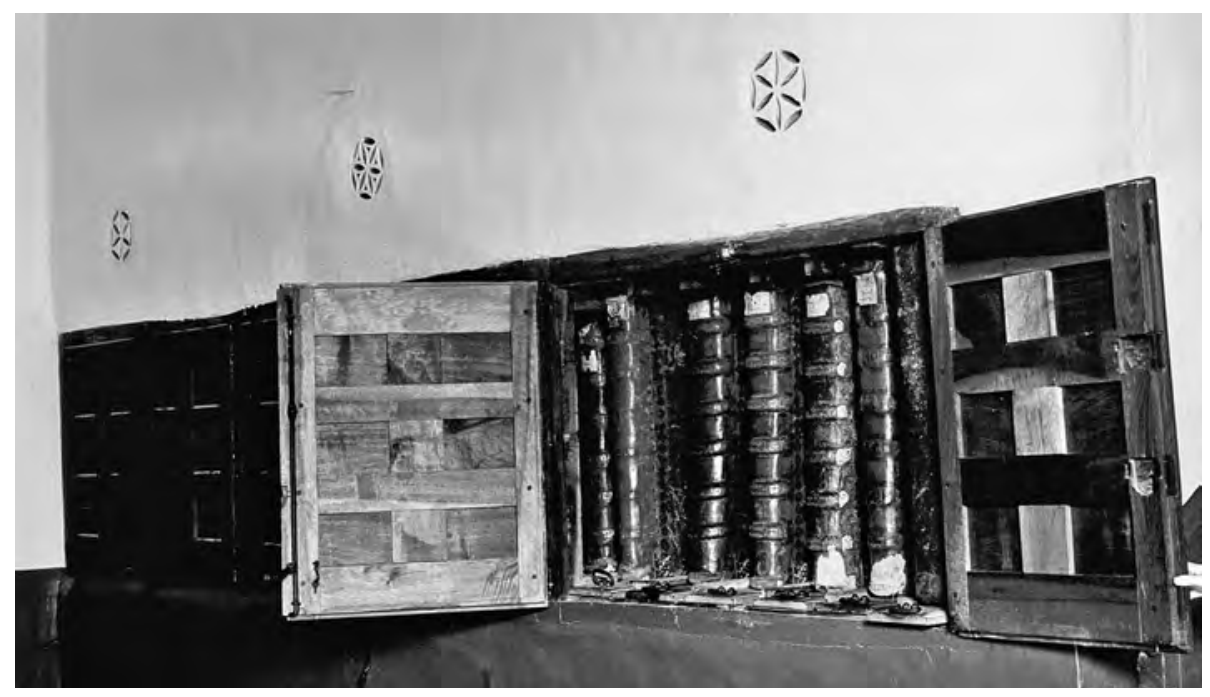

Lám. 20. Armario de cantorales (San Millán de la Cogolla, monasterio de Yuso, claustro alto, antepreciosa).

torales en el zaguán de la Preciosa (sala de acceso al coro alto, sobre la nave sur de la iglesia). Los gastos fueron abundantes pero el resultado magnífico pues cuenta el monasterio con un sistema de ordenar y acceder a los pesados y voluminosos libros de coro que no tiene parangón, consistente en un mecanismo que permite extraer la base de tabla en la que individualmente se asientan, en sentido vertical, de modo que no es necesario tocar ninguno otro. Todos se acomodan en el encajonado que se hizo en un hueco practicado en el muro norte del zaguán, o antepreciosa (lám. 20). El archivo está formado por tres cuerpos corridos en sentido horizontal, cerrados por doble hoja de cuarterones cada uno, de madera de nogal, observándose intervenciones en las cerrajas, sustituidas por fallebas. Este artilugio se debió a fray Bernardo Barral, quien se ocupó también de la adquisición de todos los materiales de soporte, pintura y encuadernación de 26 cantorales, más otro particular, con la ayuda del hermano fray Diego Sánchez ${ }^{50}$. Los volúmenes de pergamino, con letras capitales e ilumina-

50. AHN, Sección Clero, Secular-Regular, Libro 6035, s.f. (cuentas del segundo semestre de 1729, primero de 1730, primero de 1731, 1732 y de enero a marzo de 1733. En estas últimas se anota el pago a fray Bernardo Barral por hacer una cerca en la huerta de Santa Potamia, lo que parece corroborar la autoría del mecanismo. El padre Peña, siguiendo a Mecolaeta, atribuyó estos cantorales, sin conocer el documento del Archivo Histórico Nacional, al padre Barral, fallecido en 1765, del que una nota anónima decía "echó a perder la solfa de la librería y en muchas partes la hizo incantable" (Peña, J., San Millán de la Cogolla. Páginas de su historia. Logroño, 1980, reed. 1994, p. 232). 
ciones, se conservan en el citado archivo de la antepreciosa y en la biblioteca. Sus medidas oscilan entre 81,5 y $84,5 \mathrm{~cm}$ de alto y entre 52 y $61 \mathrm{~cm}$ de ancho ${ }^{51}$. Los pagos anotados en el Libro de gasto son muy detallados y de gran interés para la historia de la pintura y la restauración, pues indican la procedencia del pergamino (Zaragoza, Tarazona, Igea, Logroño y Haro), de la tinta (Zaragoza) y de una gran variedad de colores (Bilbao), así como datos sobre métodos y medios de elaboración, los instrumentos utilizados y la encuadernación, guarnecida de cantoneras de bronce. La obra se continúa pagando en 1733 y para ella se vendieron pergaminos y cantoneras viejos ${ }^{52}$. En 1818 el abad Íñigo Villanueva con motivo de su cese dio cuenta de la composición y encuadernado de doce libros de coro y de la librería que los custodiaba ${ }^{53}$. Un año antes el padre Beda Palomares elaboró índices de los cantorales ${ }^{54}$. En el inventario de bienes de la desamortización, realizado el 25 de marzo de 1836, se registran 26 libros de coro $^{55}$. Las fuentes agustinas de comienzos del siglo XX valorarán esta colección de cantorales como un "tesoro verdadero de canto gregoriano, fuente de arte netamente español, digno de preponderancia sobre el de la escuela de Solesmes, afrancesado y frío", que por entonces tanto cundía en España ${ }^{56}$.

51. El padre Olarte describe el título, número de hojas y ubicación de cada uno. Así mismo, comenta que en el archivo de Yuso no constan los copistas, pero sí conoce su existencia en el Nacional; da noticia de Barral, responsable de copiar y miniar la colección de cantorales, que había profesado el 6 de noviembre de 1710 y fue nombrado para la administración de los bienes monásticos en 1721 (Olarte, J. B., Manuscritos... núm. 11839 a 11856, nota 1139, y núm. 11421, nota 1097).

52. Durante el primer semestre de 1736 se procedió a la ordenación de la librería y del archivo, anotándose gastos de encuadernación de un índice, de cédulas para poner en los libros y de un cajón de tarjetas para los legajos, entre otros (AHN, Sección Clero, Secular-Regular, Libro 6035, s.f.).

53. AHN, Sección Clero, libro 6074 (Libro de depósito del monasterio de San Millán de la Cogolla, 1814-1835), s.f.

54. Olarte, J. B., Manuscritos..., núm. 12589 a 12599. Estos índices han sido estudiados por Fernández Fernández, T., "Una muestra del papel empleado en el monasterio de Yuso a través de los índices de los libros de coro y el estudio de sus filigranas" en Actas del VII Congreso Nacional de Historia del Papel. Madrid, 2007, pp. 301-312. Desconozco si en la tesis doctoral de Teresa Fernández, defendida en la Universidad del País Vasco (Departamento de Pintura) en octubre de 2012, con el título Los libros de coro del monasterio de Yuso y sus miniaturas. Investigación y propuestas para su conservación y restauración, se han analizado las fuentes citadas del Archivo Histórico Nacional.

55. AHN, Sección Clero, Secular-Regular, Legajos, leg. 3194 (Logroño. Desamortización. Bienes Nacionales). El número de 26 cantorales se registrará en otros inventarios del periodo (Olarte, J. B., Manuscritos..., núm. 12802). También se inventarían un buen número de libros de salmos y cantos. La biblioteca conserva varios tratados de música, ver Pérez Barriocanal, C. y Sacristán Marín, E., Catálogo de impresos de los siglos XV-XVIII de la Biblioteca del Monasterio de Yuso, San Millán de la Cogolla. Logroño, 1999.

56. Fabo, P., "San Millán de la Cogolla", Arte Español, (1914-1915), p. 371 y El convento de San Millán. Cádiz, Imp. Manuel Álvarez, s/d, p. 17. Para Avellaneda la afirmación era algo dura y dará su opinión sobre el canto gregoriano, considerando que los cantorales posteriores 
En cuanto a los instrumentos musicales utilizados en los coros de la iglesia de Yuso, las fuentes manuscritas aportan datos a partir de la conclusión de las obras de reconstrucción que se llevaron a cabo desde 1617, motivadas por el derrumbe en 1595 de la nave norte, suceso que tuvo lugar en el momento en que los frailes entraban en el coro alto cantando el salmo Miserere ${ }^{57}$. En el abadiado de fray Benito Fernández (1641-1645) se fabricaron "los dos órganos del coro bajo" y se pintaron "otros dos realejos", uno que estaba en el coro alto y otro que servía en las procesiones $^{58}$. El 12 de septiembre de 1644 el citado abad concertó con Jacinto del Río, "maestro arquitecto de hacer órganos", vecino de Navarrete, la construcción de uno grande y de un realejo, además del arreglo del órgano pequeño, para el mes de marzo de 1645 por 1.300 ducados $^{59}$. En ella se seguiría una traza firmada por el abad y el maestro que, por la terminología usada en el contrato, respondería al vocabulario de los órdenes clásicos. La caja se construiría en madera de pino a excepción del pie secreto del arquitrabe, que sería de nogal, y su trasera se cerraría con buenas tablas, dejando sus ventanas para el afinado. Se doraría todo el frente (pilastras, cornisas, frontones, figuras y demás), y policromarían algunos elementos (ramos, tallas, goteras, gallones, cartelas y figuras). Otra condición se refería a la ejecución de dos medias puertas con lienzos pintados en el anverso y reverso que se fijarían con bisagras a las últimas pilastras, de modo que, con el entablado superior, quedaría el órgano tapado para que no le entrase polvo. Esta prevención conservadora se justificaba por las quince prescripciones que se debían seguir en la confección de los órganos que, sin duda, sabrá interpretar un organero $^{60}$. Se completaría el conjunto, según la traza, con "cinco castillejos de flautas"

al siglo XVI solían ser "copias de fuentes limpias" pero que era cierto que "en muchas partes no se interpretaba la notación con rigurosa técnica" (Avellaneda, M., Guía del turista del libro El Escorial de la Rioja. Monachil (Granada), 1935, pp. 25-26).

57. "Estando en el claustro y viniendo el convento con el salmo, cuando ya entraban en la puerta del coro alto cantando el verso Benigne fac Domine, etc., cayeron las tres capillas con la pared" (Archivo de San Millán de la Cogolla (en adelante ASM), manuscrito de fray Andrés de Salazar, Historia de nuestro glorioso padre San Millán, monge y abbad de la orden de $S$. Benito, y patrón insigne de España, y de ésta su observantíssima cassa. Recopilada de los libros góthico y otros no ghóticos pero muy antiguos, y de otras escrituras de su archivo, 1607, lib. 3, cap. 5; transcripción del padre Juan Bautista Olarte).

58. ASM, manuscrito de fray Andrés de Salazar, Historia..., Adiciones al libro 3o, fols. 70 v.72 r. (escritas por fray Custodio Mecolaeta, según información del padre Juan Bautista Olarte).

59. Archivo Histórico Provincial de La Rioja (en adelante AHPLR), Valle de San Millán, Pedro Monasterio Carranza, 1643-1648, leg. 1935, fols. 60 r.-61 v. José Manuel Ramírez señala el contrato con Jacinto del Río, y posterior con Francisco de Olite, pero sin citar la fuente, en "El monasterio de San Millán de Yuso (coleccionable", El Chapitel, Revista dedicada al Patrimonio Cultural de La Rioja, no 6 (1998), pp. 41-42. Jacinto del Río, de origen aragonés, afincado en Navarrete, confeccionó diversos órganos en la región y zonas limítrofes (Ramírez Martínez, J. M., La iglesia de Navarrete, Logroño, 1988, p. 44, nota 72).

60. "1. Primeramente un rregistro de un flautado de quinçe palmos de alto de vara de Castilla en su entonación y otra media vara poco más o menos de asiento, con lo qual aya de ser un punto más vajo del tono natural, que por esto se añade un palmo más que lo que va de catorze 
que servirían solo de "apariencia y ornato". Por otro lado, el arreglo del órgano pequeño consistiría en nuevos fuelles y "laxa", el perfeccionamiento de todas las flautas, poniendo las dulzainas en el grande, y disponiéndolo para que fuese portátil, de modo que se pudiese llevar en las procesiones. El trabajo se terminaría de pagar en 1647, dos años después de la fecha de acabado, en los cuales el maestro procedería a afinar los dos órganos y realejo tan sólo por la manutención, lo que era un modo de garantizar el buen funcionamiento de la obra.

Cuarenta años después, en los primeros meses de 1685, se procedió a la limpieza de los tres órganos, aderezándolos y poniendo unos baldeses en los fuelles, lo que supuso la suma de 610 reales $^{61}$. Pese a ello, el consejo del monasterio decidió la realización de una trompeta real para el grande que costaba 1.200 reales $^{62}$. Una nueva revisión de importancia se llevó a cabo pasados diez años, en 1696. Esta vez se llamó a un maestro de hacer órganos de Viana (Navarra), Francisco de Olite ${ }^{63}$, quien debía limpiar y afinar el órgano grande, recorriendo el secreto y fuelles, y haciendo de nuevo el registro de clarines con ecos y el bajoncillo y corneta sin ellos. También limpiaría y afinaría el órgano pequeño y el realejo, haciendo a este último una nueva dulzaina; asimismo, se harían los caños que faltasen en los registros y de cuenta del monasterio correrían los baldeses para el aderezo de los fuelles. Todo el trabajo costaría 2.500 reales $^{64}$. El mismo organero

a quince; 2 . Yten es condiçión que aya de açer una octaua avierta desde lo flautado de seis palmos y medio, doble de medio arriva, añadiendo en este rrexistro, como en los demás que se siguen, el punto más baxo que dan en la condiçión primera; 3. Yten es condiçión que aya de açer un flautado tapado de seis palmos y medio de entonaçión, en la proporçión de la del punto más baxo al natural; 4. Yten es condiçión que a de açer otro tapadillo en proporçión que pide el arte; 5. Yten un anasarte o nozardo; 6. Yten una docena abierta; 7 . Yten dos quinzenas en un rexistro; 8 . Yten dos deçinobenas en un rrexistro; 9 . Yten un lleno de çinco caños que la guía de él entre en veinte dozenas; 10 . Yten una çinvala de tres caños por punto; 11 . Yten un juego de dulzaina, asentadas en el secreto como artilena; 12 . Yten una tronpeta rreal y todos los rrexistros de de (sic) las órdenes partidos como se platica; 13. Yten que para dicho órgano aya de azer tres fuelles grandes y capaçes como pide la fábrica y arte, los quales para su duraçión ayan de ser guarneçidos; 14 . Yten que las tablas del secreto prinçipales ayan de ser de nogal y las barillas o tirantes ayan de ser de fresno; 15. Yten con condiçión que ninguna de quantas flautas se pusieren y arriba ban declaradas, aya de ser tripleteada ni auierta, sino çerrada en todo su largo como lo pide el arte para que su entonaçión sea siempre firme y fina" (AHPLR, Valle de San Millán, Pedro Monasterio Carranza, 1643-1648, leg. 1935, fol. 60 v.-61 r.).

61. AHN, Sección Clero, Secular-Regular, Libro 6035, fol. 53 r. y v.

62. AHN, Sección Clero, libro 6083 (Libro de Actas del Consejo desde 1684 a 1703), fol. 3 v.

63. Su actividad fue muy extensa, ver un resumen con bibliografía en San Martín Ascacíbar, L., La actividad artística en la Rioja durante el siglo XVII. Índice de artistas y artesanos. Logroño, 2008, formato CD.

64. AHPLR, Valle de San Millán, Gabriel de Villanueva Zaldúa, 1695-1697, leg. 1948/2, fol. 34 r. y v. La notación del gasto se hizo en el segundo semestre; Ventura doró la cornisa donde se pusieron los dos registros, y de Calahorra llegó el organista Dionisio de Urrutia para ver los órganos (AHN, Sección Clero, Secular-Regular, Libro 6035, s.f.). El 9 de agosto tuvo lugar el acuerdo del Consejo para esta obra (AHN, Sección Clero, libro 6083, fol. 121 r.). 
de Viana se encargó de la composición y afino de los tres órganos de la casa en 1701 por 180 reales $^{65}$.

En el siglo XVIII las noticias sobre el órgano grande del coro bajo, el realejo del alto y el mediano se suceden. En 1705 el herrero arregló unos hierros de los registros del órgano grande, a cuya caja se pusieron bisagras nuevas en las puertas; en 1707 se serraron tablas para el órgano y en 1708 se abordó un trabajo de mayor entidad que realizó el organero José de Ripa durante nueve meses y costeó el abad (4.000 reales) ${ }^{66}$. En el grande se hicieron nuevos: el secreto principal alto; tres fuelles de marca mayor, sus puentes y palancas; todos los conductos necesarios; el cajón de los ecos; el registro de las trompetas reales; el registro de los bajoncillos; las dulzainas; dos registros de clarines ("el vno para la fachada, el otro para hazer el eco"); dos bajos de la octava; "para la dozena, tapado quinzena y diez y nouenta los primeros vajos"; "para el lleno y zinuala siete canos maiores" y "veinte i dos mouimientos de yerro y madera", más una chapa delgada clavada para asegurar el secreto. En el órgano mediano se hicieron nuevos: el secreto; tres fuelles de marca; el tablón del flautado, las plantiIlas para articular y sus voces; el tablón de los clarines para su articulación en la fachada; el secreto del corneta; los registros de buen estaño de clarines, corneta, dulzainas y flauteado; dieciséis varillas redondas para detener los clarines y hierros de los fuelles y palanca; los hierros de los registros y tres movimientos de hierro para los registros. En ambos se hizo un balaustrado con su entablado de columna a columna. En el "realillo" se hizo una tapa nueva y 126 caños para un registro de "conpuestas de Ileno", aderezándose los fuelles. Años después, en 1720, el mismo organero se encargaría de afinar los tres órganos y de la composición de los fuelles y algunos registros por 300 reales ${ }^{67}$.

En las cuentas del primer semestre de 1725 se anota el envío por su paternidad Urizar de ramilletes y teclados para los órganos y en las del segundo, la reparación del órgano pequeño del coro alto por 600 reales, al que se le pusieron seis baldeses a sus fuelles ${ }^{68}$. Las cuentas de arreglos se suceden en 1727 (tablas), 1733 (fuelles) y 1743 (hierros para los fuelles), siendo más importante el pago de 200

65. AHN, Sección Clero, Secular-Regular, Libro 6035, s.f.

66. AHN, Sección Clero, Secular-Regular, Libro 6035, s.f. Sin duda se trata del organero de Lerín (Navarra), encargado de los órganos de la catedral de Pamplona y autor de otros para iglesias navarras. Ver Jambou, L., Evolución del órgano español. Siglos XVI-XVIII. Oviedo, 1988, pp. 213 y 253. En 1729 realizó el de la parroquia de Garde (García Gainza, M. C. (dir.), Catálogo monumental de Navarra. IV* Merindad de Sangüesa Abaurrear Alta-Izalzu. Pamplona, 1989, p. 471).

67. AHN, Sección Clero, Secular-Regular, Libro 6035, s.f.

68. AHN, Sección Clero, Secular-Regular, Libro 6035, s.f.

69. AHN, Sección Clero, Secular-Regular, Libro 6035, s.f.

70. La fotografía del rótulo en el secreto no hubiera sido posible sin la colaboración del padre Fernando Sacristán y el hermano José Cuesta, a los que agradezco su interés y el mucho tiempo dedicado. José Manuel Ramírez, director general de cultura cuando se procedió a la res- 
reales a un organero por afinar el órgano del coro alto en 1751, al que siguió en 1762 la reparación por parte de un organero lego de Arlanza, que puso fuelles y conductos nuevos al órgano del coro bajo, haciéndose un tablado para resguardo de los fuelles, y costillas nuevas a los del coro alto, afinando ambos, por 602 reales de gratificación, costando la obra más de 1.580 reales ${ }^{69}$.

El órgano que hoy podemos ver en el lado sur del coro bajo (lám. 21), fue realizado en 1768 por Esteban de San Juan, según se escribió en el mecanismo interior: "Me hizo Estevan de San Juan en Logroño, año de 1768, siendo Abad el M.R. Fe. Mro Frai Plázido Bayo, Rueguen a Dios por ambos"70 (lám. 22). A excepción de este manuscrito, no se ha podido documentar el contrato con el citado organero, en un abadiado, por otro lado, de intensa actividad artística. Años después, en 1773, el Consejo del convento acordó el dorado de la caja del órgano del coro bajo con los 4.000 reales donados para este fin por fray Ángel Ruiz ${ }^{71}$. La parte superior de la caja responde a modelos rococó, con un buen tratamiento de la rocalla y guirnaldas en la decoración de sus tres torretas semicirculares y alas rectangulares, con pintura en grisalla de cabezas en las lengüetas. Pero la inferior, o pedestal, donde se encuentra el teclado es de carácter más clasicista, de sección poligonal y se articula mediante pilastras corintias que enmarcan motivos dorados y policromados de cadeneta y espejos circulares y ovales con rosetas inscritas. En la parte interior de la caja se pueden observar grafitos sobre la madera y gran parte de ella se encuentra forrada y protegida con hojas encoladas de libros impresos y manuscritos en papel, algunos del siglo XVI ${ }^{72}$ (lám. 23). José Santos de la Iglesia en su estudio sobre este órgano cita la intervención de Olite y Ripa, considerando que Esteban de San Juan lo construiría, utilizando material de los órganos anteriores, y describe su composición y orden de registros ${ }^{73}$.

En 1897, después de doce años sin utilizarse, unos organeros de Zaragoza lo arreglaron, poniendo nueva "la mano derecha de la trompeta de las batallas" y haciéndolo sonar el día de la Natividad de la Virgen ${ }^{74}$. Fue reparado en el siglo

tauración, dio noticia de la existencia de este papel en uno de los secretos y atribuyó a Francisco de Busou la caja (Ramírez Martínez, J. M., "El monasterio...", p. 42).

71. AHN, Sección Clero, libro 6085 bis (Libro de Actas del Consejo, 1727-1773), s.f.

72. La reutilización de pergaminos para guardas de libros fue habitual. Un cantoral sirvió para la encuadernación de un índice del archivo de 1656 (Olarte, J. B., Manuscritos..., núm. 9393).

73. Santos de la Iglesia Ugarte, José, Los órganos en La Rioja. Logroño, 1991, pp. 317-320 (sólo cita el Archivo Nacional como fuente documental, sin más referencia). El taller logroñés de Francisco Antonio de San Juan y sus hijos Esteban y Juan Manuel es bien conocido en el ámbito de Castilla, donde llevaron a cabo una intensa actividad (bibliografía posterior en Salas Franco, P., "Fabricación de órganos en La Rioja: los ejemplos de las iglesias de Arnedo" en Arrúe Ugarte, M. B. (coord.), Aspectos menos conocidos del arte riojano (1994-1996). Logroño, 1997, pp. 79-89).

74. APSM, № 14 Libro de Cuentas de Fábrica de la Parroquia de San Millán de la Cogolla, 1887-1939, pp. 24-25. El arreglo costó mil pesetas. 


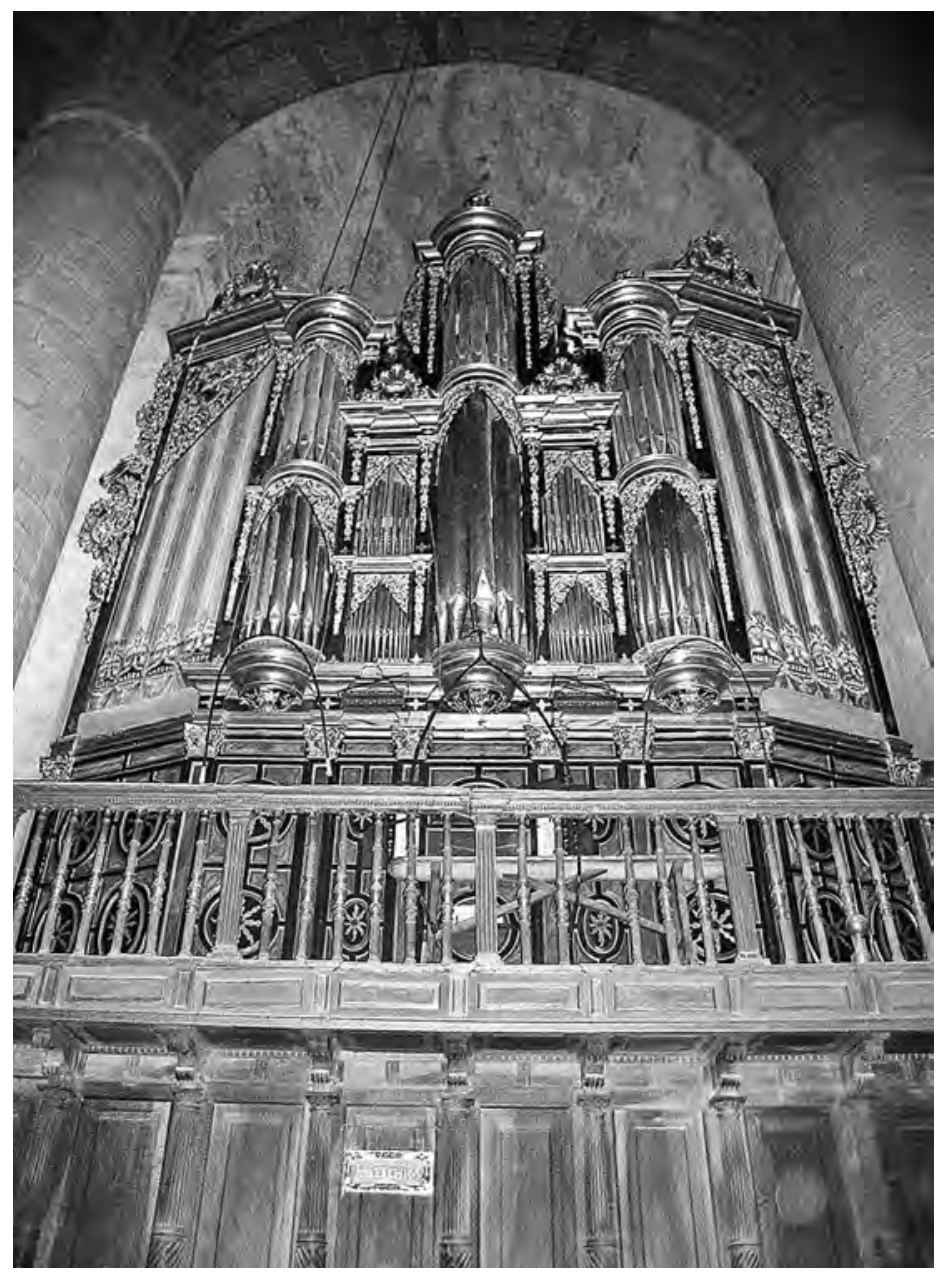

Lám. 21. Órgano en el coro bajo (San Millán de la Cogolla, monasterio de Yuso, iglesia).

Lám. 22. Inscripción de Esteban de San Juan, 1768, en el mecanismo interior del órgano del coro bajo (San Millán de la Cogolla, monasterio de Yuso, iglesia).

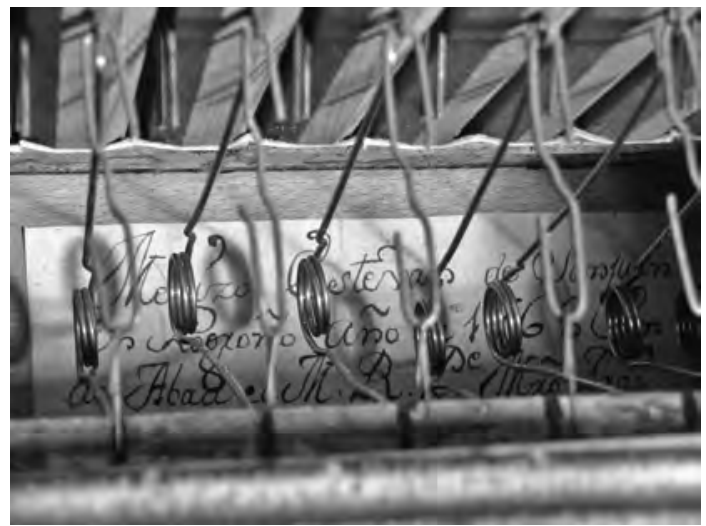




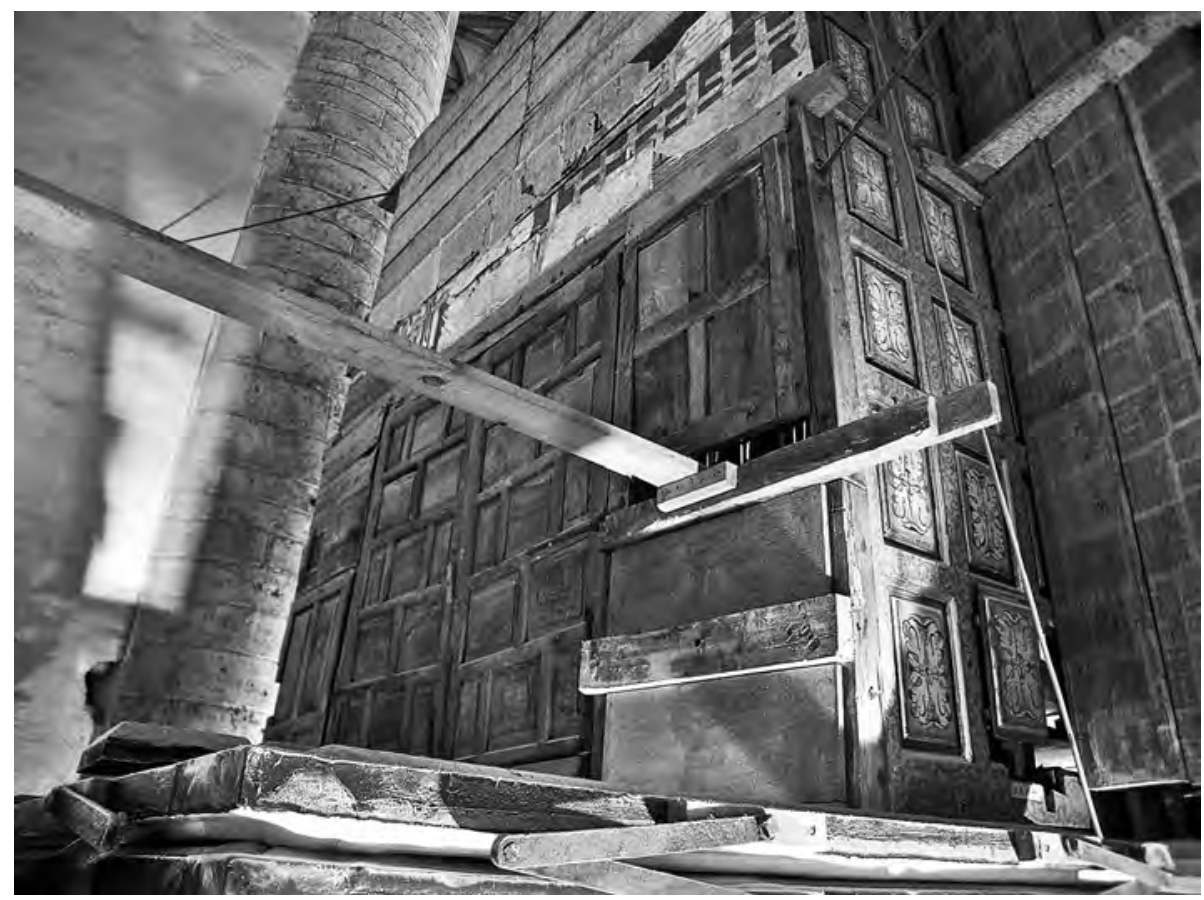

Lám. 23. Parte posterior del órgano del coro bajo (San Millán de la Cogolla, monasterio de Yuso, iglesia).

XX: en 1907 se arreglaron los fuelles; en 1908 se estañaron los tubos; en 1914 se hicieron dos banquetas, dos atriles y un nuevo aderezo de fuelles; en 1927 se arreglaron puertas y fuelles ${ }^{75}$; en 1948, se afinó y reparó $^{76}$, y entre 1988 y 1990 fue restaurado ${ }^{77}$.

75. APSM, № 14 Libro de Cuentas de Fábrica..., pp. 52-55; 60-64; 83-86; 134-136.

76. ASM, № 9, Libro de ingresos y gastos del convento de San Millán de la Cogolla (PP. Agustinos Recoletos), desde 27 de julio de 1942, fols. 77 r.

77. ASM, PO/18 (Informe de restauración del órgano de la iglesia de la Asunción del Monasterio de San Millán de Yuso (San Millán de la Cogolla), documentos sueltos, 1981-1990). La documentación del proyecto, promovido por el padre Fernando Sacristán, es muy extensa y los datos sobre el instrumento muy detallados. En principio se solicitó la visita y valoración de Gabriel Blancafort, organero de Collbató (Barcelona). Federico Acítores, del taller de organería de Torquemada (Palencia), presentó un primer proyecto. En septiembre de 1988 la Comisión de Patrimonio Histórico-Artístico aprobó la restauración por los hermanos Usabiaga, de Hernani (Guipúzcoa). En febrero de 1990, una vez concluida, se firmó el informe favorable del padre agustino José Corcuera, organista, y del organero Federico Acítores. Asimismo, se conserva un informe sobre el órgano de la Asociación Pro-Música Fermín Gurbindo. El trabajo superó los cuatro millones de pesetas. (ASM, Libro de Cosas Notables (PP. Agustinos Recoletos), 1974-1996, fol. 42 r., 44r., 48 
En cuanto a otros instrumentos que se documenten en el monasterio, sabemos que el padre fray Martín de Palencia vendió al organista Gaudioso de Logroño un clavicordio por 60 reales, según escritura de poder para su cobro del 15 de junio de $1607^{78}$. Al parecer, este iluminador de libros de coro, que estuvo al servicio de Felipe II, confeccionaba instrumentos musicales (arpas, vihuelas, monacordios, clavicordios, realejos) y era experto en la música y órgano ${ }^{79}$. En 1715 se registra la compra de un clavicémbalo por 668 reales y, curiosamente, otro en 1725 por 510 reales, junto con el gasto de ocho rollos de cuerdas para él. No deja de ser también curioso el arreglo a costa del convento de un arpa que se rompió a los músicos de San Domingo de la Calzada, en $1700^{80}$.

En el siglo XIX, con la llegada de los PP. Agustinos Recoletos, que se celebró con la participación de músicos y cantores de Nájera ${ }^{81}$, se documenta la compra de papel de música en las cuentas del Colegio de San Millán en 1879, 1886 y 1889 , así como de un método de violín y cuatro de solfeo en $1888^{82}$. Hacia 1921 la parroquia compró un armonio por 525 pesetas $^{83}$, y se registra el pago de lengüetas para otro, procedente de Puente, en $1933^{84}$, así como, su pertenencia al Colegio y ubicación en el coro alto del grande y en la Sala de Recreo de los Coristas del segundo, en el inventario de 1934".5 . En 1950 se anota la compra de un armonio para el Colegio y otros dos para la sacristía,

v., 51 v., 55 r. y v.). En el pilar oriental se encuentra una placa con el rótulo siguiente: "La restauración de este órgano ha sido posible gracias a la ayuda prestada por la Fundación Banco Exterior. Los restauradores fueron los Hnos. Alejandro y Agustín Usabiaga. 1-6-89/2-2-90". Se procedió a la limpieza de la caja en la última restauración de la iglesia, antes citada (2005-2011).

78. Olarte, J. B., Manuscritos..., núm. 5038; ver también núm. 3653, nota 476 sobre fray Martín de Palencia, y Peña, J., San Millán..., pp. 93-94.

79. Goicoechea, C., "Biografías emilianenses", Berceo, no 9 (1948), p. 541 (según datos de la obra de fray Alonso del Corral de 1649). Otros profesos en San Millán relacionados con la música fueron los cantores Jerónimo Sáenz de Arregui (1659), Manuel Méndez (1712), Rafael del Caño (1722) y Vítores Benito (1783); los organistas Pablo Serra (1697), José Gómez (1705), Veremundo Martínez (1766), Francisco Briones (1797), Mauricio Alberni (1829) y Agustín Vallejo (1830), y los bajonistas Fernando López (1791) y Luis Vázquez (1797) en Zaragoza Pascual, E., "Monacologio emilianense (1500-1833)", Studia monástica, no. 29, 2 (1987), pp. 301, 308, $311,313,323,325,327-328$ y 331.

80. AHN, Sección Clero, Secular-Regular, Libro 6035, s.f.

81. ASM, № 1 Libro de cuentas de cargo y data del Colegio de San Millán de la Cogolla (PP. Agustinos Recoletos), 1878-1901, fols. 3 r. Se anotan pagos a los danzantes, y mil reales a los músicos y cantores de Nájera para la inauguración del Colegio el 1 de septiembre.

82. ASM, № 1 Libro de cuentas..., fol. 9 r., 74 r. y v., 85 r. y 91 v.

83. APSM, № 14 Libro de Cuentas de Fábrica..., pp .104-106

84. ASM, № 4 Libro de Cuentas de cargo y data del Colegio de San Millán de la Cogolla (PP. Agustinos Recoletos), 1923-1940, pp. 237-238 y 240.

85. ASM, № 13 Libro Inventario del Colegio de San Millán de la Cogolla (PP. Agustinos Recoletos), 1934-1948, fols. 1 r.-11 v. 
uno para el coro y otro para el noviciado, ambos servirían para el aprendizaje de los novicios ${ }^{86}$.

Una aportación histórica de gran significado que ofrece el monasterio de San Millán, aunque de muy difícil conservación, es el conjunto de grafitos existente en los muros de la zona del antiguo noviciado benedictino. Situado en la planta tercera, con acceso desde el claustro alto, ocupaba el espacio correspondiente a la cabecera de la iglesia, torre y antiguas sacristía y sala capitular. Documentada su construcción desde el siglo XVI, con las consiguientes reformas del siglo XVII y modificaciones del XVIII, la zona cayó en desuso progresivo hasta el precario estado en el que actualmente se encuentra. Afortunadamente, durante el proyecto de ejecución de la Fase I de las obras de restauración parcial de la iglesia, dirigidas por Óscar Reinares, con el patrocinio de la Fundación San Millán de la Cogolla, se elaboró un informe histórico artístico entre agosto de 2003 y enero de 2004 sobre los grafitos ${ }^{87}$, pudiendo constatar la riqueza informativa de esta fuente para la historia y vida conventual emilianense, pero, asimismo, para un buen número de disciplinas, entre ellas la música. La cantidad de grafitos es inconmensurable pues se observan hasta en cuatro capas de enlucidos, desde finales del siglo XVI al siglo XX. En su mayoría se grabaron pero también los hay al carbón, sanguina y grafito. Los motivos que se pudieron ver se clasificaron en figurados (humanos, animales, híbridos, vegetales, objetos, arquitectura y escenas); geométricos (líneas y figuras); decorativos; numéricos (cifras y cronologías), epigráficos (letras, firmas, inscripciones y escrituras musicales); cuentas y calendarios; símbolos y juegos. El carácter plástico fundamental, dado el medio y la esencia o naturaleza del propio lenguaje, es la línea, a veces segura y firme, otras, refinada y meticulosa, suelta y clara y, en general, variada y expresiva. La representación aúna todas las características de los sistemas primitivos: ausencia de perspectiva, escorzo y volumen, o convencionalismos (isocefalia, jerarquización, ley de la frontalidad). La mayoría de los autores fueron los que, habiendo tomado el hábito temporalmente, siguieron su formación en el noviciado, bajo la dirección de un monje de avanzada edad, hasta la proclamación firme de su propósito de profesar en la orden, profesión que acordaba el Consejo del monasterio. De algunos se conocen los nombres, porque dejaron constancia

86. ASM, Libro de Cosas Notables (PP. Agustinos Recoletos), 1948-1974, pp. 48-51. Uno de ellos debió ser el traído desde Zaragoza en 1949 por el que se pagó 3.446,25 pesetas a Mariano Viu; otro costó 3.601,25 pesetas y se compró a la vez que obras de música (ASM, Libro de ingresos y gastos del Convento (PP. Agustinos Recoletos), 1948-1969, fols. 14 v., 16 r., 19 v., 27 v y 28 v.).

87. Arrúe Ugarte, M. B., Martínez Ocio, M. J. y Navarro Bretón; M. C., Informe históricoartístico sobre los grafitos existentes en la zona del antiguo noviciado y torre, del monasterio de San Millán de la Cogolla de Yuso (La Rioja), contrato para proyecto de investigación OTRI, 2004, Universidad de La Rioja-CORESAL S.A. (OTEM040415B). 
de ello, pero otros son anónimos, pudiéndose identificar grafitos de un mismo autor por el estilo o carácter de lo representado o trazado. En algún caso se puede rastrear su vida posterior en la historia de la Comunidad.

Entre los grafitos figurados relacionados con objetos musicales, se ha observado en dos ocasiones la forma de sendos cordófonos ${ }^{88}$. Ambos parecen dibujados por el mismo autor, se representan esquemáticos, de frente, con dos orificios en ese en la caja y un largo mástil semicurvado que acoge una cuerda. (lám. 24). Otro objeto que aparece en una serie de grafitos es la campana que pende del chapitel de la torre, refundición de una medieval del siglo XIII, Ilamada "la bomba" por sus dimensiones y peso. Se asocia a la propia construcción de la torre a partir de 1619 y su colocación debió suponer un celebrado acontecimiento, por lo que no extraña que fuese objeto de atención de los "dibujantes" del noviciado, formando parte de varios grafitos que representan su arquitectura. El más significativo es el dibujado por el hermano Bernardo La Cuesta, en el que el perfil de la campana se muestra nítido entre el conjunto del chapitel con su cubierta escamada ${ }^{89}$ (lám. 25). Una torre campanario muy detallada, con ocho campanas y una figura tocando una de ellas, grabará otro novicio en la estancia contigua en un periodo anterior $^{90}$ (lám. 26).

Los grafitos epigráficos son muy numerosos y entre ellos se repite con frecuencia la inscripción "HIC EST CHORVS" (lám. 27)91, que los novicios podían observar en paneles de madera dorada colocados en los dos coros de la iglesia, lo que indica la importancia que para ellos tenía, pues en muchos casos la regla benedictina castigaba las faltas en su comportamiento con postraciones en tierra durante los oficios del coro (lo que también se constata en más de un grafito). Se han registrado varias escrituras musicales, algunas con inscripciones, no siempre completas o de fácil lectura, sobre las que se quiere llamar aquí la atención para que futuros análisis especializados arrojen luz sobre el tipo y carácter de la composición y su importancia histórica.

En la estancia de la torre se han localizado cuatro pentagramas en el segundo enlucido, por tanto datado hacia 1725 . Dos con notas cuadradas, uno sin ellas, y un cuarto de mayor definición y detalle, asimismo con doce notas cuadradas con la inscripción debajo "el villano que le dan zebollita", una variante

88. Uno en la estancia contigua a la torre y el otro en la estancia más meridional (paneles II c $3^{\circ}$ y IV s $3^{\circ}$ del informe citado, que anotaré para facilitar su consulta).

89. Situado en el espacio interior de la torre (panel I g $2^{\circ}$ ). El autor dejó escrito al lado del dibujo del chapitel que había hecho la magna obra en los cuatro meses que vivió en esa cámara de la torre.

90. Panel II e $3^{\circ}$. A la derecha de la torre se representó un Crucificado y a la izquierda la única imagen que se conserva de Nuestra Señora de la Cueva, de Autol.

91. Panel II e $3^{\circ}$. 


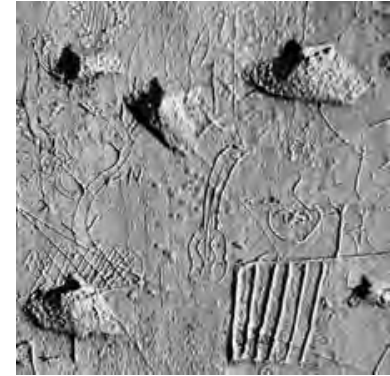

Lám. 24. Grafito con representación de cordófono, anónimo, último tercio del s. XVII (San Millán de la Cogolla, monasterio de Yuso, antiguo noviciado).

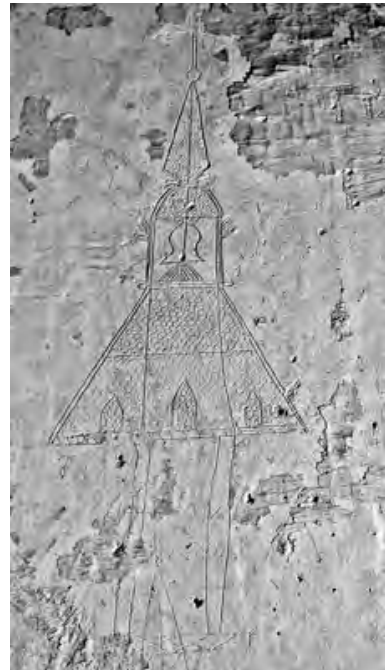

Lám. 25. Grafito con representación de chapitel con campana, Bernardo La Cuesta, segundo cuarto del s. XVIII (San Millán de la Cogolla, monasterio de Yuso, antiguo noviciado).

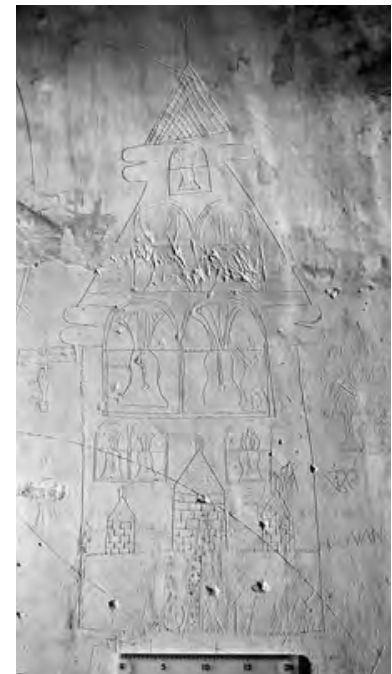

Lám. 26. Grafito con representación de torre campanario, anónimo, último tercio del s. XVII (San Millán de la Cogolla, monasterio de Yuso, antiguo noviciado).

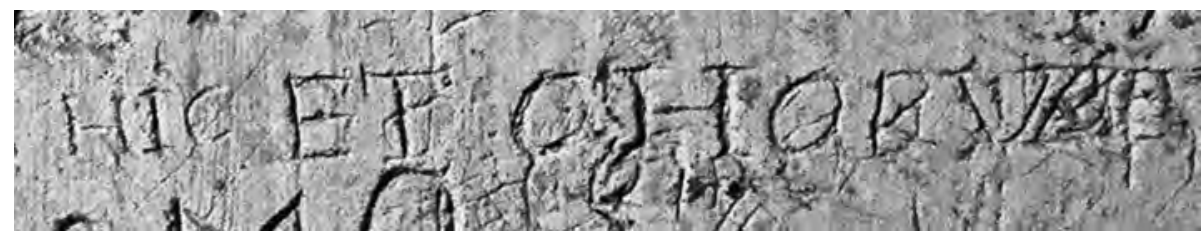

Lám. 27. Grafito con inscripción "HIC ET CHORVS", anónimo, último tercio del s. XVII (San Millán de la Cogolla, monasterio de Yuso, antiguo noviciado).

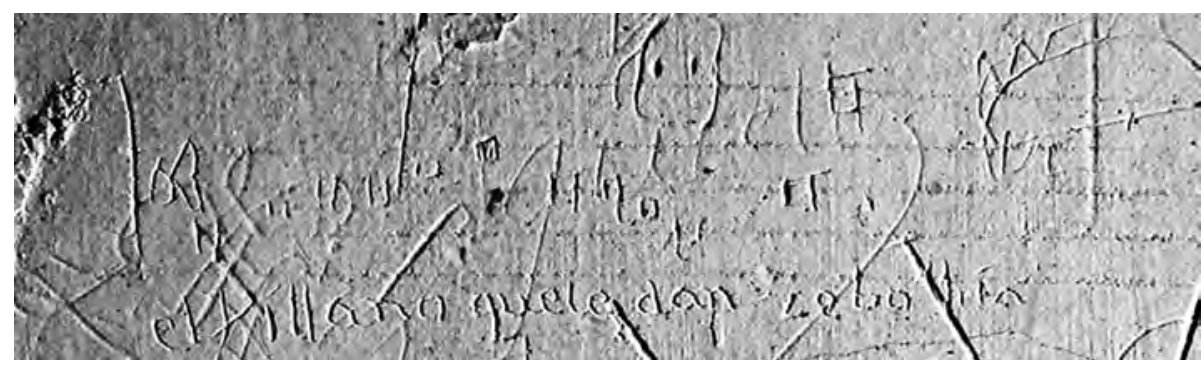

Lám. 28. Grafito con escritura musical "el villano que le dan zebollita", anónimo, segundo cuarto del s. XVIII (San Millán de la Cogolla, monasterio de Yuso, antiguo noviciado). 
de pieza de danza, difundida en los siglos XVI y XVII, que demuestra el conocimiento musical del novicio que lo realizó ${ }^{92}$ (lám. 28).

En la estancia contigua y sobre el tercer enlucido, correspondiente a los varios documentados entre 1733 y 1760 , se encuentran grafitos que representan cinco tetragramas con notas cuadradas, tres con inscripción bajo ellos, una ilegible y las otras "Santus" y "Salve", lo que nos habla del carácter religioso de esta música. De igual modo, dos pentagramas, uno con notas cuadradas y otro con dos notas romboidales, bajo el que se inscribe: "difto Lunes $1^{\circ}$ Noct $^{\circ}$ con ( ) Mies 3) lan ( )/ Do Mares y Juebes Umg tantum Sal( )" (probablemente referido a los oficios de difuntos; encontrándose próximo a grafitos de tenebrarios) ${ }^{93}$. También se han observado lo que parecen listados de notas musicales, que sirvieron posiblemente de apunte para algún tipo de ejercicio o de referencia para memorizar unas determinadas secuencias de sonidos ${ }^{94}$.

En la estancia meridional, en el enlucido tercero del siglo XVIII, se localizaron dos tetragramas. Uno con letra " $\mathrm{S}$ " inicial, notas cuadradas rehundidas y una inscripción inferior: "(s) al ve"95. El otro, al que se superpone un tercero, así mismo con notas cuadradas, bajo el que se inscribe: "lue sacerdos magu qui iaze os suis dueuit Deos î uento î justus Secular" ${ }^{\prime \prime 6}$. Se encuentra precedido de la silueta de una mano derecha (lám. 29).

Entre los gafitos que reproducen cuentas o calendarios, se encuentra uno en la estancia tercera en el enlucido de 1725, parcialmente oculto por el posterior, en el que se contabilizaron el número de oficios en el coro, en dos hiladas de líneas verticales unidas por una horizontal inferior, con cruces latinas elevadas e iniciada con las inscripciones: "oficios" e "item"

Hasta aquí la información más destacada, pero permítase un último apunte sobre la simbología de la música en este monasterio benedictino. Las fuentes emilianenses hablan de la existencia de unas campanillas "muy pequeñas, a

92. Dos en el panel I g $2^{\circ}$ y otras dos en el panel I i $2^{\circ}$. El de la inscripción mide 0,045 m alto $\times$ 0,18 $\mathrm{m}$ ancho; y se localiza a 1,69 $\mathrm{m}$ del suelo y a 0,06 $\mathrm{m}$ de la esquina sur. Agradezco a José Miguel Lorenzo Arribas, su interés por este grafito y el informe que elaboró cuando se lo dimos a conocer, fundamentado con un amplio aparato crítico (puede verse una síntesis en Centro Virtual Cervantes. Rinconete. Patrimonio Histórico. Grafitos históricos (14). "El villano de San Millán" (http://cvc.cervantes.es/el_rinconete/anteriores/enero_13/30012013_01.htm).

93. Paneles II c $3^{\circ}$ y II e $3^{\circ}$.

94. "Re - fa ( )/ Re - fa $2 \%$ mi fa $3 \%$ mi fa $4 \%$ fa fa $5 \%$ fa la $6 \%$ ut sol $7 \%$ ut fa $8^{\circ}$ " y "R IA/ R /N/ M/ VI FA/ F, IA/ VT SO/ VT FA 8" (panel II c $3^{\circ}$ ).

95. Medidas: 0, $03 \mathrm{~m}$ alto $\times$ 0,10 $\mathrm{m}$ ancho; localización: a 0,08 $\mathrm{m}$ del remate del zócalo (panel IV q $3^{\circ}$ ).

96. Medidas: conjunto: $0,185 \mathrm{~m}$ alto $\times 0,35 \mathrm{~m}$ ancho; mano: $0,185 \mathrm{~m}$ alto $\times 0,135 \mathrm{~m}$ ancho; $0,047 \mathrm{~m}$ alto (incluida la inscripción) x 0,288 $\mathrm{m}$ ancho; localización: a 0,875 $\mathrm{m}$ del suelo y a $2,18 \mathrm{~m}$ de la esquina este (panel IV s $3^{\circ}$ ).

97. Panel III h $2^{\circ}$. 


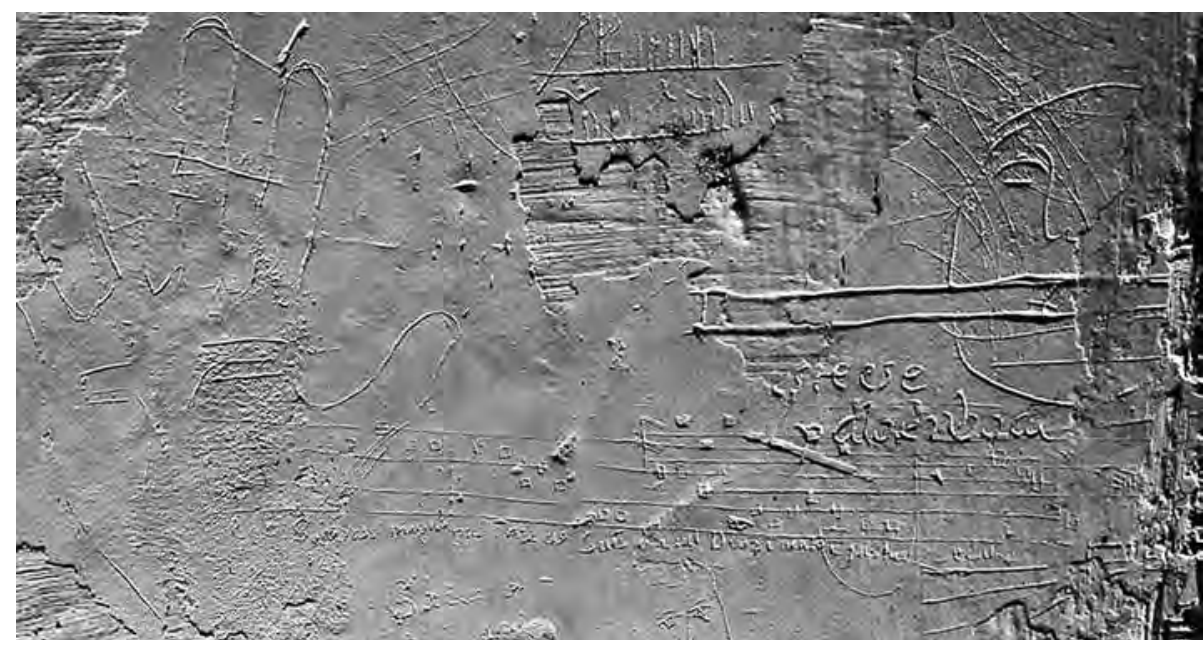

Lám. 29. Grafito con escritura musical, anónimo, s. XVIII (San Millán de la Cogolla, monasterio de Yuso, antiguo noviciado).

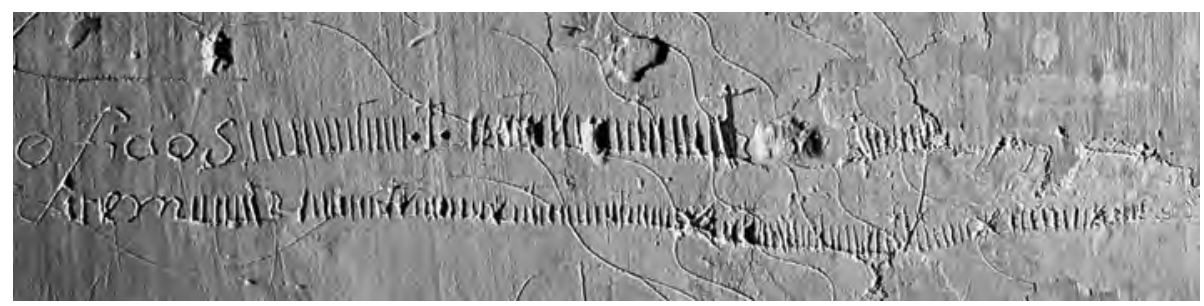

Lám. 30. Grafito con cuenta de oficios, anónimo, segundo cuarto del s. XVIII (San Millán de la Cogolla, monasterio de Yuso, antiguo noviciado).

modo de cencerros", que el padre fray Andrés de Salazar cita en su historia de san Millán de 1607, como una de las antigüedades notables de la casa, de la que ya dio testimonio el monje Fernando en su crónica de la traslación de las reliquias del Santo (h. 1225) ${ }^{98}$. Desconocemos cómo eran ${ }^{99}$, y en qué momento de la edad Media se confeccionaron, pero su milagroso tañido era fuente de buenos o malos presagios en la vida del convento. Era el Santo el que, al decir de

98. ASM, manuscrito de fray Andrés de Salazar, Historia..., lib. II, cap. 11.

99. Según la descripción de Salazar, las dos campanillas estaban colgadas de cadenillas de hierro en un soporte con forma de capitel de bronce sobredorado, "labrado muy curiosamente". Comenté estas piezas en "Contribución del Real Monasterio de San Millán de la Cogolla (La Rioja) a la historia de la orfebrería en España. Un relevante patrimonio de platería desaparecido" en Rivas Carmona, J. (coord.), Estudios de Platería. San Eloy 2002. Murcia, 2002, p. 59. 
las fuentes monásticas medievales, avisaba a los frailes de una muerte o adversidad, pero estos nefastos sucesos se tornan felices en la edad Moderna. Así, Salazar narra que una noche "estando el santo convento haciendo las oraciones antes de maitines, se tañeron las dichas campanillas por tres veces, haciendo agradable armonía y consonancia". Pese al miedo del momento producido por esta señal, treinta días después se justificó por la llegada de la noticia de la sentencia favorable de un grave pleito que el monasterio mantenía en Roma hacia $1572^{100}$. Por tanto, un instrumento aparentemente insignificante de finalidad tan sencilla, como el aviso o la llamada de atención sobre un momento de la ceremonia religiosa, se convierte en un objeto digno de ser inventariado ${ }^{101}$, junto a la riqueza de las arcas y relicarios de oro, plata, marfil, esmaltes y piedras preciosas de los bienes del patrimonio monástico, formando parte de la historia del santo patrón, a quien la tradición atribuía su uso cuando apacentaba ganado. Sirvan las noticias aquí ofrecidas, como las campanillas, de comunicación a los musicólogos sobre la aportación histórica del monasterio de San Millán de la Cogolla a su disciplina ${ }^{102}$.

100. Era abad Pedro de Medina y Salazar cita testigos del acontecimiento, algunos todavía vivos cuando el escribe.

101. Se inventarían en 1601 "pendientes de vn planchón a modo de chapitelillo como florón" (AHN, Sección Clero, leg. 3102, s.f.).

102. Agradezco a las investigadoras M $M^{a}$ Jesús Martínez Ocio y Mํa Cruz Navarro Bretón su ayuda en la investigación del patrimonio histórico-artístico del monasterio de San Millán, que inicié en 1997, a su archivero el padre Juan Bautista Olarte por tantas facilidades y orientaciones, y a la Comunidad de PP. Agustinos Recoletos por su hospitalidad. Así mismo, mi agradecimiento a Thomas L. Schmitt por hacerme partícipe del presente monográfico sobre "qué es la música". 